Research papers

\title{
Seasonal and interannual variations in coccolithophore abundance off Terceira Island, Azores (Central North Atlantic)
}

\author{
Áurea Narciso ${ }^{\mathrm{a}, *}$, Francesca Gallo ${ }^{\mathrm{a}}$, André Valente ${ }^{\mathrm{b}}$, Mário Cachão ${ }^{\mathrm{c}}$, Lluïsa Cros ${ }^{\mathrm{d}}$, \\ Eduardo B. Azevedo ${ }^{a}$, Joana Barcelos e Ramos ${ }^{\mathrm{a}}$ \\ ${ }^{a}$ Centre of Climate, Meteorology and Global Change and CITA-A, University of Azores, 9700-042 Angra do Heroísmo, Portugal \\ ${ }^{\mathrm{b}}$ MARE - Marine and Environmental Sciences Centre, Faculty of Sciences, University of Lisbon, 1749-016 Lisboa, Portugal \\ c Instituto Dom Luiz, Faculty of Sciences, University of Lisbon, 1749-016 Lisboa, Portugal \\ ${ }^{\mathrm{d}}$ Institut de Ciencies del Mar (CSIC), Passeig Marítim de la Barceloneta, 37-49, E-08003 Barcelona, Spain
}

\section{A R T I C L E I N F O}

\section{Article history:}

Received 16 February 2015

Received in revised form

23 January 2016

Accepted 29 January 2016

Available online 1 February 2016

Keywords:

Living coccolithophores

Seasonality

Phytoplankton ecology

Azores archipelago

\begin{abstract}
A B S T R A C T
In order to characterize the natural coccolithophore community occurring offshore Azores and to determine their annual and interannual patterns, monthly samples were collected, from September 2010 to December 2014, in the photic zone off Terceira Island.

The present study revealed a clear seasonal distribution and a considerable interannual variability of the living coccolithophore community. The highest coccolithophore abundances were observed during spring and winter months, especially due to the smaller species Emiliania huxleyi and Gephyrocapsa ericsonii. In fact, the highest biomass period was registered during April 2011, associated with enhanced abundance of the overcalcified morphotype of E. huxleyi, which was possibly influenced by subpolar waters and subsequent upwelling conditions. The highest abundances of Gephyrocapsa muellerae were recorded during June 2011 and 2014, indicating that this species characterizes the transition between the period of maximum productivity and the subsequent smoother environmental conditions, the first and the later stages of the phytoplankton succession described by Margalef, respectively. During summer to early fall, a gradual decrease of the overall coccolithophore abundance was observed, while the species richness (Margalef diversity index) increased. A subtropical coccolithophore assemblage mainly composed by Umbellosphaera tenuis, Syracosphaera spp., Discosphaera tubifera, Rhabdosphaera clavigera and Coronosphaera mediterranea indicated the presence of surface warmer waters accompanied by reduced mixing and low nutrients concentration. During late fall to winter, the coccolithophore abundance increased again with a concomitant reduction in species diversity. This is potentially linked to low sea surface temperatures, moderate nutrients concentration and surface mixed layer deepening. During 2011, colder and productive waters led to an increase in the total coccolithophore abundances. On contrary, during 2012, characterized by milder environmental conditions, an increase in the diversity of the community was prevalent. The noticeably coccolithophore response to variations in the main physical variables and on main traditional nutrients corroborates the importance of this group as proxy of marine environmental conditions in the past.
\end{abstract}

(c) 2016 Elsevier Ltd. All rights reserved.

\section{Introduction}

Coccolithophores are pelagic unicellular algae, members of the haptophyte class Prymnesiophyceae Hibberd, distinguished by the ability to produce calcite platelets called coccoliths, which surround the living cell and form an exoskeleton called coccosphere (e.g. Winter and Siesser, 1994; Young, 1994). Coccolithophores, known since the late Jurassic (Hay, 2004), have an ocean wide distribution and represent the most productive calcifying organisms on Earth (Honjo, 1996). They also affect the ocean-atmosphere carbon dioxide exchange

\footnotetext{
* Corresponding author. Present address: CIIMAR-Madeira, Caminho da Pentead 105, Funchal, Portugal.

E-mail address: aureanarciso@uac.pt (Á. Narciso).
}

and produce dimethyl sulfide (DMS), which stimulates cloud formation, thus actively participating in the climate system (Berger et al., 1989; Westbroek et al., 1993; Rost and Riebesell, 2004). Since this calcifying group has potential to fossilize as calcareous nannoplankton, it becomes a (paleo)environmental proxy directly dependent on temperature, salinity, and nutrients and light availability (e.g., McIntyre and Bé, 1967; Giraudeau et al., 1993; Winter and Siesser, 1994).

Coccolithophores usually dominate the phytoplankton biodiversity in the oligotrophic central gyres of the oceans (e.g. McIntyre and Bé, 1967; Winter et al., 1994; Ziveri et al., 2004), being also markedly present at temperate (e.g. Giraudeau and Bailey, 1995; Cachão et al., 2000) and high latitude eutrophic regimes (e.g. Andruleit, 1997; Baumann et al., 2000).

Although the geographic distribution of coccolithophores has been well studied over the last four decades, its seasonal dynamics 
as well as the relation between the species abundances and the several environmental parameters, only more recently have been documented (e.g. Beaufort and Heussner, 2001; Hagino et al., 2005; Andruleit, 2007; Chen et al., 2007; Baumann et al., 2008; Dimiza et al., 2008; Silva et al., 2008; Malinverno et al., 2009; Moita et al., 2010; Schiebel et al., 2011; Guerreiro et al., 2013; Mergulhão et al., 2013; Guerreiro et al., 2014; Sun et al., 2014). In the North Atlantic Subtropical Gyre (NAST; Longhurst et al., 1995) context, where the present research was developed, studies of Haidar and Thierstein (2001), Schiebel et al. (2011) and Silva et al. (2013) are noteworthy. The NAST province is characterized by relatively weak winter deep mixing, despite significant year to year variability, with high rates of productivity during the months of January to March, where the coldest sea surface temperatures and quick consumption of nutrients are observed. In contrast, primary production rate is minimum in September, coincident with the summer thermal maximum (Waniek et al., 2005). Thus, the mixing of water masses and seasonal stratification may determine the phytoplankton flux and species composition by controlling the availability of nutrients (Storz et al., 2009).

The present study is an output of the project ROPICO-2 "Responses of phytoplankton communities from the Subtropical North Atlantic Gyre to increasing $\mathrm{CO}_{2}$ concentrations and consequent carbonate chemistry changes in the ocean, Azores". In this paper we discuss the distribution of the living coccolithophore community offshore Terceira Island (Azores archipelago), as well as its seasonal and interannual variability and the forcing mechanisms. Afterwards, this study will provide knowledge that might be used to determine potential shifts on the coccolithophore natural assemblage, especially in diversity and abundance, associated with the ocean acidification.

\section{Oceanographic setting}

The Azores archipelago, located in the middle of the North Atlantic Ocean between $37-40^{\circ} \mathrm{N}$ and $25-31^{\circ} \mathrm{W}$, comprises nine volcanic islands divided in three groups according to its geographical distribution. The present research was developed off Terceira Island, which is positioned in the central group (Fig. 1). This archipelago lies in a transition zone between the North Atlantic Current (NAC), located at north, and the Azores Current (AC), at south, both resulting from the Gulf Stream (Klein and Siedler, 1989). To the north, the NAC consists of several narrow current bands (jets) that meander eastward across the North Atlantic from 40 to $53^{\circ} \mathrm{N}$ (Bower and von Appen, 2008). Most of the NAC recirculates northward, however, below a line between $40^{\circ} \mathrm{N}, 35^{\circ} \mathrm{W}$ and $45^{\circ} \mathrm{N}, 28^{\circ} \mathrm{W}$, the jets veer southward and the average flow develops a south component (Reverdin et al., 2003). The northernmost islands of the archipelago, such as the Terceira Island, are under the influence of these southward jets that transport colder, less saline, and possibly more productive waters of subpolar origin into the archipelago. To the south, the $\mathrm{AC}$ is a quasi-permanent feature throughout the year centered between $33^{\circ}$ and $35^{\circ} \mathrm{N}$, with strong meanders and eddies (Klein and Siedler, 1989; Santos et al., 1995) which cause recirculation patterns that affect the islands. Associated to the AC there is a major thermohaline front, the Azores Front, separating fresher and colder waters to the north and warmer and saltier water masses to the south (Gould, 1985).

\section{Material and methods}

\subsection{Sample collection}

Sampling was conducted every month, whenever possible, between September 2010 and December 2014. A total of 28 samples were collected from the integrated upper $10 \mathrm{~m}$ of the water column, offshore Terceira Island $\left(38^{\circ} 37^{\prime} \mathrm{N}, 27^{\circ} 15^{\prime} \mathrm{W}\right.$; distance to the shore $\approx 2.16$ nautical miles), by deploying vertically a $10 \mathrm{~m}$ long tube in the seawater. Each sample was then mixed in a 201 container and subsequently subsampled for phytoplankton microscopy observation and acquisition of physico-chemical data (temperature, salinity and nutrients) (Fig. 1).

\subsection{Physico-chemical parameters}

Sea Surface Temperature (SST) was determined in situ, from the 201 container, with a common mercury thermometer, calibrated in the laboratory. Salinity was determined in laboratory by measuring the water samples conductivity using a WTW (Cond 340i).

Samples $(55 \mathrm{ml})$ for nutrient determination were filtered through a polyethersulfone (PES) $0.2 \mu \mathrm{m}$ syringe filter and stored at $-20^{\circ} \mathrm{C}$ until being analyzed. Concentrations of nitrate $\left(\mathrm{NO}_{3}^{-}\right)$, phosphate $\left(\mathrm{PO}_{4}^{3-}\right)$ and silicate $\left(\mathrm{Si}(\mathrm{OH})_{4}\right)$ were measured following Hansen and Koroleff (1999), by means of a spectrophotometer (Cary 60 Probe, Varian). The detection limit for seawater analysis was $\pm 0.1 \mu \mathrm{mol}^{-1}$ for nitrate, $\pm 0.02 \mu \mathrm{mol} \mathrm{l}^{-1}$ for phosphate and $\pm 0.5 \mu \mathrm{mol} \mathrm{l}{ }^{-1}$ for silicate.

\subsection{Coccolithophore analysis}

Seawater samples between 1.5 and 21 were filtered over nitrate cellulose Whatman filters $(0.45 \mu \mathrm{m}$ pore size, $47 \mathrm{~mm}$ diameter $)$ using a low pressure vacuum system. The filters were then rinsed with a bicarbonate solution adjusted to $\mathrm{pH} 10$, to remove sea salt, and left to dry in covered petri dishes at room temperature. A randomly chosen triangular section of each filter was cut and permanently mounted on a slide. Coccospheres and coccoliths were identified and counted under polarized light microscope (Leitz Ortholux II Pol-BK) at $1250 \times$ magnification. At least 100 coccospheres and 400 coccoliths were counted through random fields of view. When it was not possible to find these amounts, the counting was extended to $10 \mathrm{~mm}^{2}$ of the examined area. The absolute abundances (Coccosphere $1^{-1}$; Coccolith $\mathrm{I}^{-1}$ ) were estimated from the number of counted coccospheres $(N)$ and coccoliths $(N)$ in the examined area multiplied by the ratio of total filter area $(T A)$ to examined area $(E A)$, and then divided by the volume of filtered water $(V)$ :

Coccosphere/Coccolith $\mathrm{l}^{-1}=[N \times(A T / A E)] / V$.

Taxonomy of coccolithophores was performed according to Cros and Fortuño (2002), Young et al. (2003), Jordan et al. (2004) and Frada et al. (2010).

To estimate the diversity of the coccolithophore assemblage, the Margalef diversity index (Margalef, 1968) for each sampled month was calculated according to the formula $D_{\mathrm{Mg}}=(S-1) / \ln N$, where $S$ is the number of species and $N$ is the total number of individuals.

\subsection{Multivariate analysis}

To explore and statistically demonstrate the relationships between coccolithophores and the environmental variables a Canonical Correspondence Analysis (CCA) was conducted using PAleontological STatistics (PAST) vers. 3.1 (Hammer et al., 2001). This multivariate method, commonly used in ecology, was performed upon a data matrix with five physico-chemical parameters (temperature, salinity and three nutrients) and abundances of main coccolithophores as columns (variables) and the samples as rows (cases). Taxa were considered relevant within the coccolithophore assemblage when occurred simultaneously at least in $20 \%$ of the samples as both coccospheres and coccoliths. The resulting CCA ordination triplot diagram displays at once species (their coccosphere and coccolith abundances) as points, samples as points and environmental variables as vectors. 


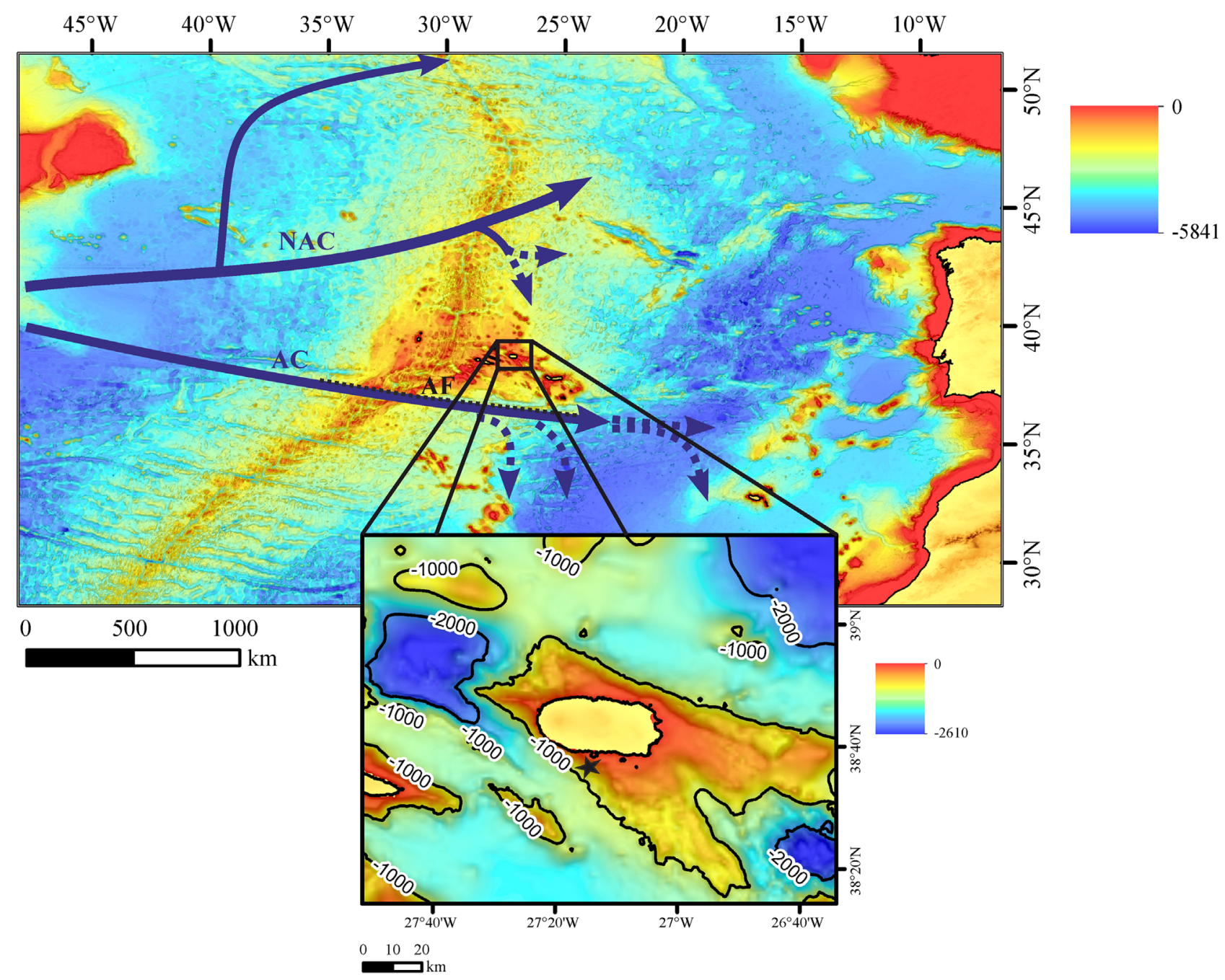

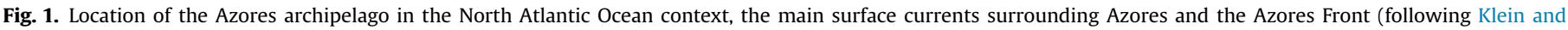

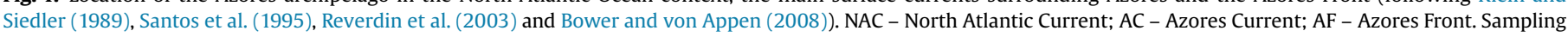
location is represented by a star. Bathymetry and elevation data derived from IOC, IHO and BODC (2003). Map Datum is D_WGS_1984 in GCS.

\subsection{Satellite derived data}

Satellite-derived maps of Sea Surface Temperature (SST) and surface currents were used to examine the oceanographic conditions in the studied site. The SST maps were derived from observations of the Moderate Resolution Imaging Spectroradiometer (MODIS) aboard the Aqua satellite. The $11 \mu \mathrm{m}$ (daytime) SST monthly Level 3 standard mapped image (SMI) MODIS Aqua Product, processed and distributed by the Ocean Biology Processing Group (OBPG), was applied. This product is generated every 30 days at $4 \mathrm{~km}$ resolution, on equi-rectangular projection, and was obtained from the OBPG website (http://oceancolor.gsfc.nasa.gov/ $\mathrm{cms} /$ ). Only SST data flagged with best quality was used. Geostrophic velocity fields were derived from the delayed time "Up-todate" global gridded product of sea level anomalies and produced by Ssalto/Duacs at Collecte Localization Satellites (CLS, 2009). This product is generated every 7 days at $1 / 3^{\circ}$ resolution and was obtained from the AVISO website (http://www.aviso.oceanobs.com/ en/data.html). Data from surface geostrophic currents were only available until August 2013. The monthly maps of SST and weekly maps of surface currents were used to make the averaged maps for the winters (January-March) and summers (July-September) from 2011 to 2014 (Fig. 2a and b). The data of April was also computed in order to support our findings about the pattern evidenced by some coccolithophore taxa during this month (Fig. 2c).

\section{Results}

\subsection{Physico-chemical data}

The annual sea surface temperatures ranged from 14.5 to $24^{\circ} \mathrm{C}$, showing some variability from year to year. An overall warming occurred from June to October, with surface temperatures between 16 and $24{ }^{\circ} \mathrm{C}$, followed by a surface water cooling to a minimum of $14.5^{\circ} \mathrm{C}$ and subsequent mixing and enhanced nutrient supply in the photic zone. The largest temperature range occurred in 2011, where the coldest January $\left(14.5^{\circ} \mathrm{C}\right)$ and the warmest August were registered $\left(24^{\circ} \mathrm{C}\right)$ (Table 1).

The analysis of the averaged SST maps shows similar conditions during 2011 and 2014, although slightly more rigorous in 2011 (colder winter and warmer summer). From all images it is clearly visible the presence of colder southward intrusions of subpolar origin surrounding Terceira Island (Fig. 2a and b). The winter of 2012 was unusually mild, with particularly high SSTs (Fig. 2a). An intrusion of colder water, probably from a subpolar origin, together with a localized cold water patch along the southern coast, is also present in the vicinity of our site during April 2011 (Fig. 2c). 

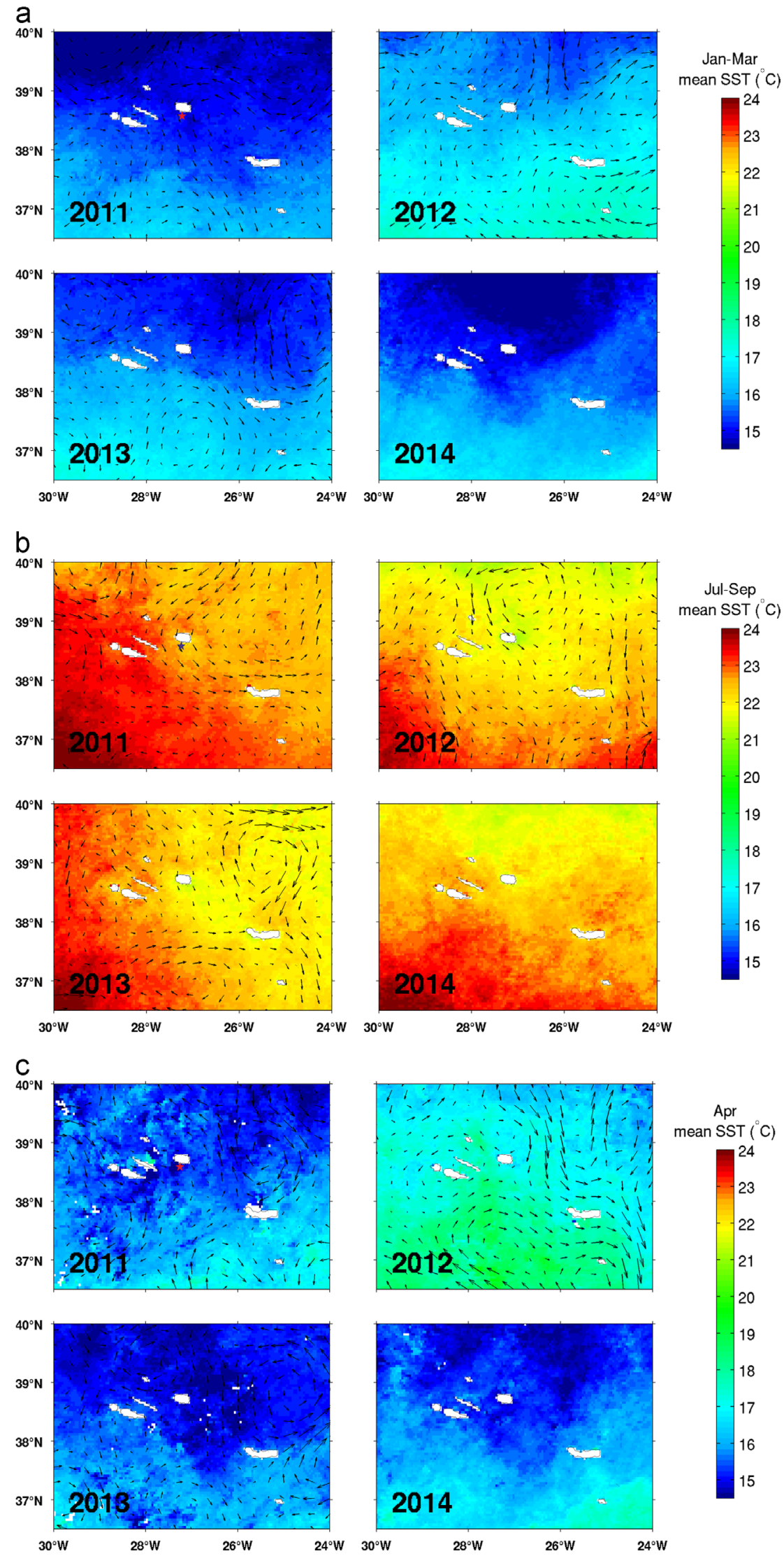

Fig. 2. Satellite-derived SST and surface geostrophic currents averaged from 2011 to 2014: a) during winter (January-March); b) during summer (July-September); and c) during April. Data from surface geostrophic currents was only available until August 2013. Sampling location is represented by a star. 


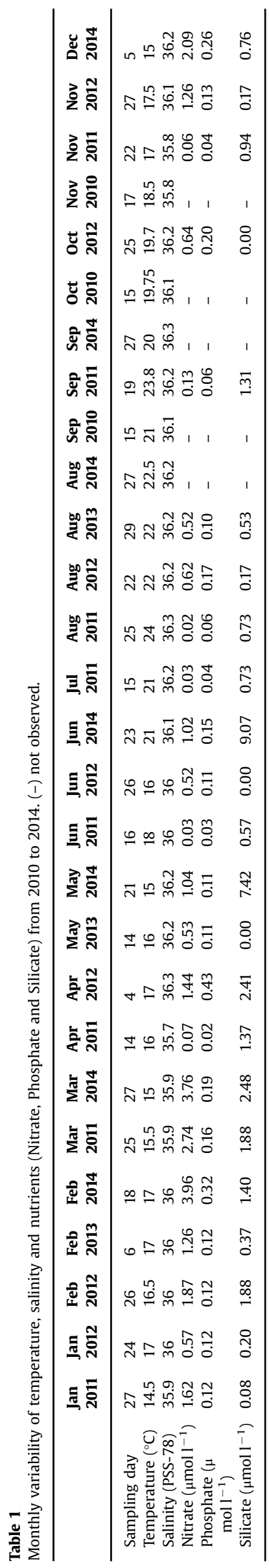

Concerning the salinity, the range of values during the 4 years of sampling was relatively narrow (35.7-36.3) (Table 1).

Nitrate concentrations show similar annual trend in all analyzed years, with maxima from January to March and minimum during the summer months. The phosphate concentrations remain very low all over the year, from 2010 to 2014, with a slight tendency to increase during the winter. The silicate content presents, in general, intermediate values from February to March and lower values during the summer. Extremely high values (anomalous) were registered during May and June 2014 (Fig. 3a, b and c; Table 1). The analysis of Fig. 3 shows also that 2014 was the year in which the highest concentrations for all nutrients were observed.

\subsection{Coccolithophore assemblage description}

The highest coccolithophore abundances (Coccosphere $\mathrm{l}^{-1}$ and Coccoliths $\mathrm{l}^{-1}$ ) were observed during the spring of 2011, more precisely during April, whereas the lowest abundances were observed during the summer of the same year, in September (Fig. 4). Maxima in the monthly absolute abundances were also more frequent during 2011 (Fig. 4). A total of 37 distinct taxa of coccolithophores were recognized under polarized light microscope, with an additional Scanning Electron Microscope (SEM) analysis: 4 at genus level, 27 species, 1 subspecies and 5 varieties. The relative abundances of the most relevant coccolithophores are indicated in Table 2 (coccospheres) and 3 (coccoliths). The complete list of taxa, including the rare specimens, can also be consulted in the Appendix A. Selected taxa are illustrated in Appendix B (Plates 1 and 2).

Emiliania huxleyi (dominated by the morphotype type A) together with Gephyrocapsa ericsonii are the most abundant species within coccospheres whereas the former dominates the coccolith assemblage. Gephyrocapsa muellerae and Gephyrocapsa oceanica are also present but the latter with minor importance. Other significant taxa within coccospheres, in order of decreasing abundance, are: Syracosphaera spp. (dominated by Syracosphaera pulchra), Umbellosphaera tenuis, Calcidiscus leptoporus, Umbilicosphaera sibogae, Michaelsarcia spp., Coronosphaera mediterranea, Discosphaera tubifera, Rhabdosphaera clavigera and Calciosolenia sp. (Table 2). The ordered sequence for coccolith assemblage is U. tenuis, Syracosphaera spp. (dominated by S. pulchra), U. sibogae, C. leptoporus, C. mediterranea, R. clavigera, Calciosolenia sp. and D. tubifera (Table 3).

Fig. 5 shows the monthly relative abundances of the eight most significant taxa within the living community (coccospheres), which represent about $85 \%$ of the assemblage. The detailed analysis of this figure points out the highest abundances of G. muellerae during the later spring conditions (June) of 2011 and 2014, even exceeding the relative abundances of $E$. huxleyi and G. ericsonii. During the month and year of the highest coccolithophore abundances (April 2011), the E. huxleyi values reach a maximum and G. ericsonii a minimum. This interval is also coincident with the greatest amount of the overcalcified morphotype of E. huxleyi type A (or "closed" morphotype), which reach 20\% (see Table 2).

$U$. tenuis shows higher concentrations during summer, moderate presence during October $(2010,2012)$, and is almost absence during the remaining months. Syracosphera spp. occurs more frequently under the later summer and early fall conditions. C. leptoporus and $U$. sibogae are present all over the year, although the former shows an abundance peak during the summer.

Concerning the coccolith data (Table 3 ), the results are similar to those observed for coccospheres, with variations in a very few taxa records. This observation is corroborated by high correlation coefficients for 2011 and $2013(r>0.7)$, and moderate for 2012 $(0.5<r<0.7)$. The record of $G$. oceanica observed during June 2014 , which duplicates in the coccolith assemblage, is responsible for the low correlation $(r<0.5)$ displayed for that year.

According to Margalef diversity index (Fig. 6) the more diversified assemblage occurs during earlier fall (October 2010, 2012). In contrast, during spring months, especially in May 2013, the species 

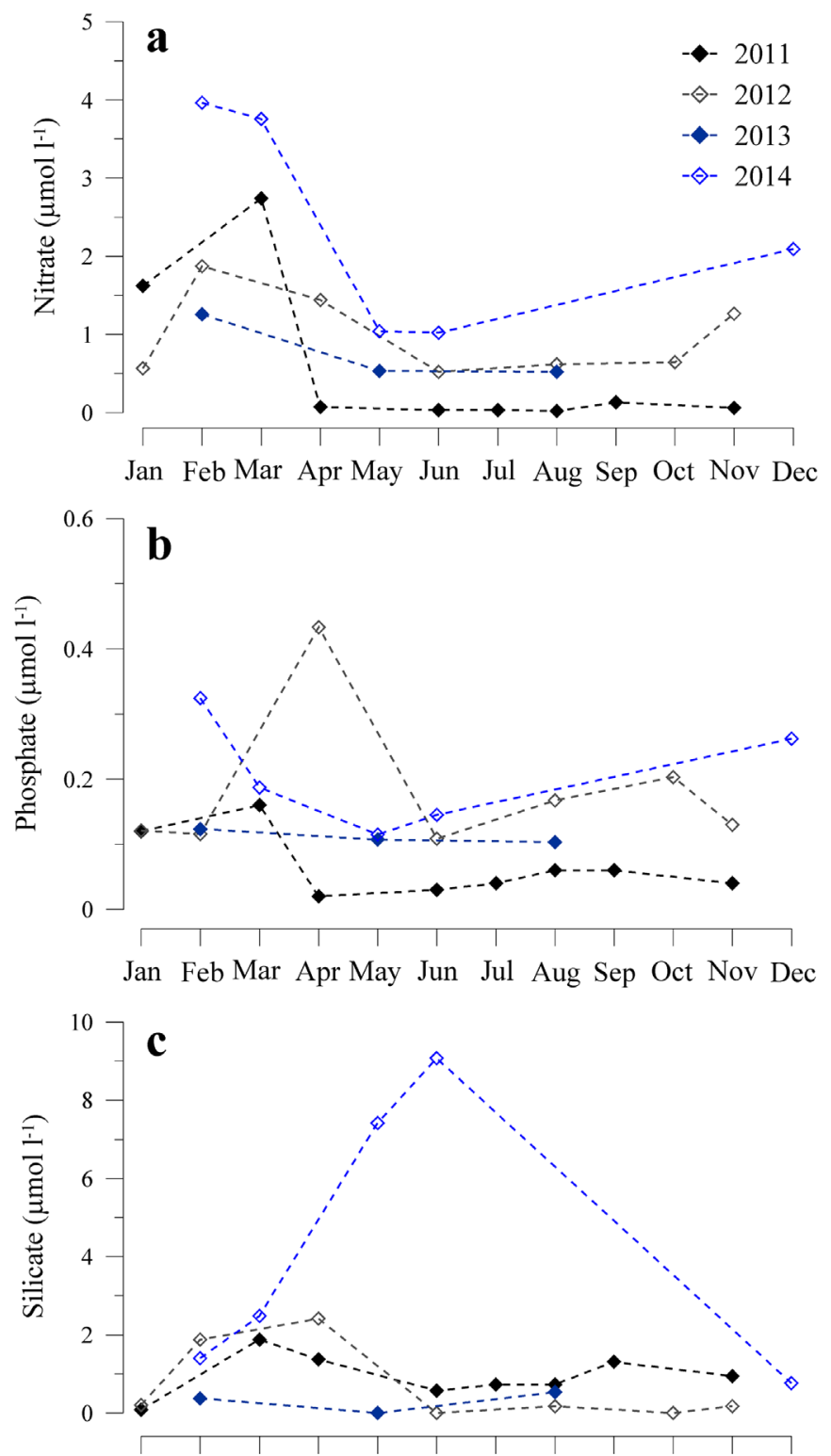

Jan Feb Mar Apr May Jun Jul Aug Sep Oct Nov Dec

Fig. 3. Monthly measurements of nutrients concentration from 2011 to 2014: a) Nitrate; b) Phosphate; and c) Silicate.

richness is lower. An interannual variability can also be extracted from this figure. Thus, during 2012 there is a general tendency for more diversified communities. Similar patterns are observed for 2011 and 2014, with some separation from January to March.

\subsection{Multivariate analysis}

The first three axes of CCA explained 97\% of total data variability with the first axis 1 and 2 containing 57.1\% and 32.7\%, respectively, of the total information. Their ordination diagram is represented on Fig. 7. The eigenvalues and its percentage variance in the speciesenvironment relationship of the CCA analysis are depicted in Table 4. The scores of taxa, samples and environmental variables can also be consulted in Table 5. Quantitative environmental variables and the direction of its maximum change are indicated by green vectors, which length is proportional to the rate of change among samples. In the present analysis, the first axis is associated with increasing silicate and decreasing phosphate, while the second is associated with
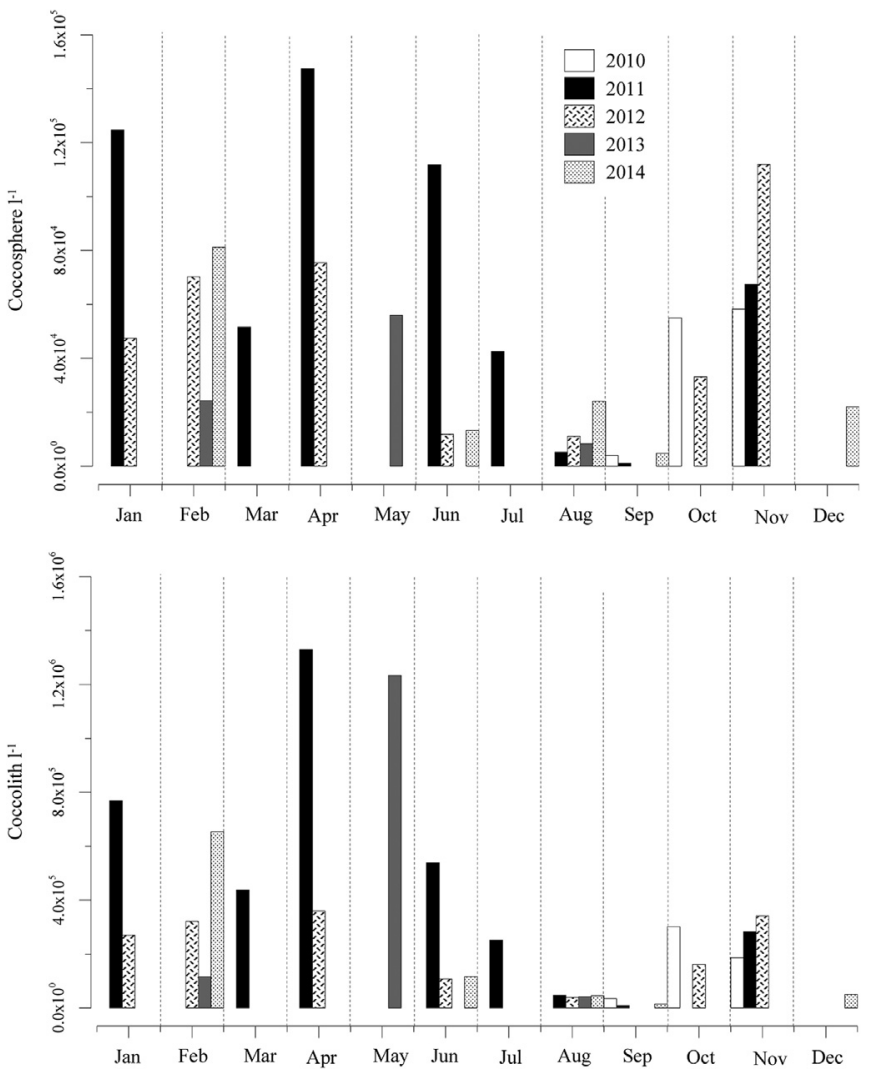

Fig. 4. Monthly absolute abundances for total coccospheres and coccoliths from September 2010 to December 2014.

increasing both SST and salinity and decreasing nitrate. SST, salinity and silicate show stronger correlations with the community variation due to the longer vectors in opposition to phosphate and nitrate. SST and salinity are the strongest correlated variables, which is implicit by the small angle between them.

Concerning the behavior of the community to external factors, $G$. muellerae and $G$. oceanica are strongly associated with higher silicate concentrations. $U$. tenuis and Syracosphaera spp. are strongly positively correlated with higher SST and salinity water masses. D. tubifera and $R$. clavigera have also affinity for these environments but in a lesser extent. The ordination diagram also shows a positive correlation between U. sibogae, H. carteri, E. huxleyi, Calciosolenia sp. and G. ericsonii and the environmental variable nitrate. These same taxa present also positive correlations with the presence of phosphate. The position of the overcalcified E. huxleyi in the triplot reveals a positive correlation with the nitrate variable, as well as negative correlation with SST and salinity. $C$. leptoporus and $C$. mediterranea are positively influenced by all variables present in the third and fourth quadrants. The close position of the scores of coccospheres and coccoliths for the same taxa may indicate that, in general, the coccolith content is representative of the living coccolithophore community.

The position of samples in the triplot demonstrates the strong relationship between the summer samples and warmer and saltier waters, as well as between the winter samples and more mesotrophic conditions.

\section{Discussion}

Coccolithophore seasonality is well expressed in our results. During the spring months a high overall coccolithophore abundance is observed (Fig. 4), essentially due to E. huxleyi and G. ericsonii, the latter in lesser degree. E. huxleyi is known by the more productive surface- 
Table 2

Relative abundances of coccolithophore taxa present in the coccosphere assemblage, for each sampled month from 2010 to 2014. Maxima values are selected; (-) not observed.

\begin{tabular}{|c|c|c|c|c|c|c|c|c|c|c|c|c|c|c|c|c|c|c|c|c|c|c|c|c|c|c|}
\hline $\begin{array}{l}\text { Total coccospheres } \\
\%\end{array}$ & $\begin{array}{l}\text { Jan } \\
2011\end{array}$ & $\begin{array}{l}\text { Jan } \\
2012\end{array}$ & $\begin{array}{l}\text { Feb } \\
2012\end{array}$ & $\begin{array}{l}\text { Feb } \\
2013\end{array}$ & $\begin{array}{l}\text { Feb } \\
2014\end{array}$ & $\begin{array}{l}\text { Mar } \\
2011\end{array}$ & $\begin{array}{l}\text { Apr } \\
2011\end{array}$ & $\begin{array}{l}\text { Apr } \\
2012\end{array}$ & $\begin{array}{l}\text { May } \\
2013\end{array}$ & $\begin{array}{l}\text { Jun } \\
2011\end{array}$ & $\begin{array}{l}\text { Jun } \\
2012\end{array}$ & $\begin{array}{l}\text { Jun } \\
2014\end{array}$ & $\begin{array}{l}\text { Jul } \\
2011\end{array}$ & $\begin{array}{l}\text { Aug } \\
2011\end{array}$ & $\begin{array}{l}\text { Aug } \\
2012\end{array}$ & $\begin{array}{l}\text { Aug } \\
2013\end{array}$ & $\begin{array}{l}\text { Aug } \\
2014\end{array}$ & $\begin{array}{l}\text { Sep } \\
2010\end{array}$ & $\begin{array}{l}\text { Sep } \\
2011\end{array}$ & $\begin{array}{l}\text { Sep } \\
2014\end{array}$ & $\begin{array}{l}\text { Oct } \\
2010\end{array}$ & $\begin{array}{l}\text { Oct } \\
2012\end{array}$ & $\begin{array}{l}\text { Nov } \\
2010\end{array}$ & $\begin{array}{l}\text { Nov } \\
2011\end{array}$ & $\begin{array}{l}\text { Nov } \\
2012\end{array}$ & $\begin{array}{l}\text { Dec } \\
2014\end{array}$ \\
\hline B. bigelowii & - & - & - & - & - & - & - & - & - & - & - & - & 0.89 & - & - & - & - & - & 5.88 & - & - & - & - & - & - & - \\
\hline C. leptoporus & 0.87 & 0.90 & 2.70 & 1.10 & 1.75 & 1.72 & 3.16 & - & 2.44 & 0.93 & 1.09 & - & 0.89 & 1.75 & 6.36 & 1.25 & 2.42 & - & 5.88 & 15.56 & 0.86 & 2.34 & 0.64 & 0.88 & 4.58 & 4.49 \\
\hline Calciosolenia sp. & 0.87 & 0.90 & 0.90 & - & - & - & - & - & - & - & - & - & - & - & 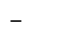 & 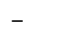 & - & - & - & - & 1.72 & 3.91 & - & 0.88 & 0.76 & - \\
\hline C. mediterranea & 0.87 & 0.90 & 0.90 & 2.20 & - & - & - & - & - & 0.93 & - & - & - & - & - & 3.75 & - & - & - & 2.22 & 0.86 & 3.91 & - & - & 0.76 & - \\
\hline D. tubifera & 0.87 & - & - & - & - & - & - & - & - & - & - & - & 0.89 & - & 4.55 & - & 0.81 & 1.79 & - & - & 2.59 & 4.69 & - & - & - & - \\
\hline E. huxleyi & 26.09 & 36.04 & 33.33 & 29.67 & 65.79 & 37.93 & 44.21 & 39.62 & 84.55 & 23.15 & 32.61 & 16.67 & 36.61 & 59.65 & 16.36 & 35.00 & 48.39 & 44.64 & 17.65 & 24.44 & 30.17 & 16.41 & 18.47 & 47.37 & 39.69 & 53.9 \\
\hline E. hux. overcalcified & 2.61 & 1.80 & 6.31 & 5.49 & 0.88 & 6.90 & 20.00 & - & - & 0.93 & 1.09 & - & 0.89 & - & - & - & - & - & - & - & - & - & - & 2.63 & 1.53 & - \\
\hline F. profunda & - & - & - & - & - & - & - & - & - & - & - & - & - & - & - & - & - & 0.21 & - & - & 0.16 & 0.78 & - & - & 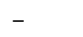 & 4.49 \\
\hline G. ericsonii & 35.65 & 45.05 & 40.54 & 28.57 & 21.05 & 25.86 & - & 47.2 & 2.44 & 32.41 & 29.35 & - & 33.93 & 22.81 & 43.64 & 2.50 & 4.03 & 23.21 & 17.65 & 8.89 & 38.79 & 32.81 & 67.52 & 32.46 & 15.27 & 6.74 \\
\hline G. muellerae & 10.43 & 4.50 & 9.91 & 14.29 & 3.51 & 15.52 & 21.05 & 2.83 & 10.57 & 39.81 & 15.22 & 50.00 & 20.54 & 3.51 & 9.09 & 8.75 & 32.26 & 3.57 & 5.88 & 11.11 & 1.72 & 5.47 & 4.46 & 4.39 & 20.61 & 14.6 \\
\hline G. oceanica & 2.61 & 1.80 & 0.90 & 1.10 & - & 3.45 & 6.32 & 5.66 & - & - & 6.52 & 16.67 & 1.79 & - & 0.91 & 5.00 & - & - & - & 2.22 & 0.86 & 0.78 & 0.64 & - & 8.40 & - \\
\hline H. carteri & - & - & 1.80 & 2.20 & - & 1.72 & - & - & - & - & - & - & - & - & - & - & - & - & - & - & 2.59 & 0.78 & - & - & 0.76 & - \\
\hline Michaelsarcia spp. & 0.87 & 2.70 & - & 5.49 & 0.88 & - & - & 0.94 & - & - & - & - & - & - & - & - & - & - & - & - & 1.72 & 1.56 & - & 1.75 & 1.53 & - \\
\hline S. apsteinii & - & - & - & - & - & - & - & - & - & - & - & - & - & - & - & - & - & - & - & - & - & 0.78 & - & - & 0.76 & - \\
\hline R. clavigera & 0.87 & - & - & - & - & - & - & - & - & - & - & - & - & - & 2.73 & - & - & - & - & - & 1.72 & 7.81 & - & - & - & - \\
\hline Syracosphaera spp. & 5.22 & 3.60 & 1.80 & 8.79 & 0.88 & 3.45 & 1.05 & 2.83 & - & - & - & 2.38 & - & 5.26 & 2.73 & 15.00 & - & 14.29 & 29.41 & 17.78 & 6.90 & 7.03 & 4.46 & 4.39 & 2.29 & 3.37 \\
\hline U. tenuis & - & - & - & - & - & - & - & - & - & - & 11.96 & 4.76 & - & 3.51 & 11.82 & 27.50 & 4.03 & - & 11.76 & 11.11 & 4.31 & 7.03 & 0.64 & 0.88 & - & 3.37 \\
\hline U. sibogae & 4.35 & 0.90 & - & - & - & 1.72 & 2.11 & 0.94 & - & 1.85 & 2.17 & - & - & - & 0.91 & 1.25 & - & - & - & 6.67 & 0.86 & 1.56 & 1.91 & 1.75 & 1.53 & 1.12 \\
\hline Holococcoli & 3.48 & 0.90 & - & 1.10 & - & 1.72 & - & - & - & - & - & - & - & - & - & - & - & 1.7 & - & - & - & 0.78 & - & - & - & - \\
\hline Undetermined spp. & 3.48 & - & 0.90 & - & 5.26 & - & 2.11 & - & - & - & - & 9.52 & 3.57 & 3.51 & 0.91 & - & 8.06 & 10.71 & 5.88 & - & 4.31 & 1.56 & 1.27 & 2.63 & - & 7.87 \\
\hline
\end{tabular}

Table 3

Relative abundances of coccolithophore taxa present in the coccolith assemblage, for each sampled month from 2010 to 2014. Maxima values are selected; (-) not observed.

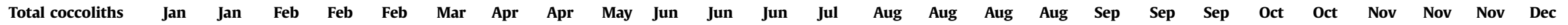
$\begin{array}{lllllllllllllllllllllllllll}\% & 2011 & 2012 & 2012 & 2013 & 2014 & 2011 & 2011 & 2012 & 2013 & 2011 & 2012 & 2014 & 2011 & 2011 & 2012 & 2013 & 2014 & 2010 & 2011 & 2014 & 2010 & 2012 & 2010 & 2011 & 2012 & 2014\end{array}$

\begin{tabular}{|c|c|c|c|c|c|c|c|c|c|c|c|c|c|c|c|c|c|c|c|c|c|c|c|c|c|c|}
\hline B. bigelowii & - & - & - & - & - & - & - & - & - & - & - & - & - & . & . & - & - & - & - & - & - & - & - & - & - & - \\
\hline C. leptoporus & 2.26 & - & 2.76 & 2.78 & 3.92 & 2.04 & - & 0.79 & 0.53 & 0.96 & 0.36 & - & 0.91 & 1.00 & 2.84 & 0.51 & 0.88 & 0.21 & 0.88 & 3.05 & 0.47 & 2.72 & 0.20 & 2.09 & 2.01 & 9.95 \\
\hline Calciosolenia sp. & 0.42 & 0.48 & 2.37 & 0.46 & - & - & - & 0.20 & - & - & - & - & 0.30 & - & - & - & - & 0.41 & - & - & 1.26 & 2.08 & 0.20 & 0.63 & 2.76 & - \\
\hline C. mediterranea & - & 0.48 & 1.58 & 0.93 & - & - & - & - & - & - & - & - & 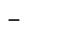 & - & 0.52 & 5.57 & - & 0.21 & - & 0.76 & 1.10 & 2.72 & - & 0.63 & 1.00 & - \\
\hline D. tubifera & - & - & - & - & - & - & - & - & - & - & - & - & - & 0.20 & 1.29 & - & - & 0.41 & 2.63 & - & 0.47 & 0.32 & - & - & - & - \\
\hline E. huxleyi & 75.28 & 85.40 & 71.40 & 71.00 & 82.57 & 63.34 & 63.32 & 85.71 & 97.10 & 57.31 & 60.91 & 9.56 & 63.84 & 84.26 & 44.44 & 40.76 & 65.35 & 86.78 & 61.40 & 59.54 & 77.60 & 54.33 & 79.88 & 84.13 & 64.16 & 52.24 \\
\hline E. hux. overc & 5.37 & 0.95 & 8.28 & 4.87 & 2.61 & 9.16 & 25.82 & - & - & 1.15 & 1.67 & - & 3.63 & 0.20 & 0.78 & 0.51 & - & - & - & - & - & 0.00 & - & 6.05 & 2.76 & - \\
\hline F. profunda & - & 0.32 & 0.79 & 0.23 & 0.54 & 1.22 & 0.12 & - & - & - & 0.24 & - & - & - & - & - & 0.44 & 0.21 & - & - & 0.16 & 1.44 & - & 0.42 & 0.25 & 13.93 \\
\hline G. ericsonii & 1.98 & 0.79 & 0.20 & 3.02 & 1.96 & 0.61 & 0.47 & 0.20 & - & 2.12 & 0.72 & - & 1.51 & 0.20 & 0.78 & 0.76 & 1.32 & 1.03 & - & 1.53 & 0.79 & 1.28 & 1.79 & 0.63 & 0.50 & 6.468 \\
\hline G. muellerae & 5.65 & 8.73 & 6.51 & 8.35 & 4.58 & 12.63 & 7.24 & 6.15 & 2.11 & 34.62 & 17.64 & 47.81 & 26.78 & 9.36 & 12.14 & 5.57 & 22.37 & 3.51 & 2.63 & 15.27 & 2.84 & 6.89 & 5.18 & 1.25 & 9.52 & 13.93 \\
\hline G. oceanica & 2.12 & 1.90 & 2.37 & 2.32 & 1.20 & 2.65 & 0.58 & 2.58 & 0.26 & 1.15 & 1.91 & 40.44 & 1.21 & 0.60 & 3.88 & 4.56 & 0.44 & 0.41 & 0.88 & 3.05 & 0.79 & 5.13 & 1.79 & 0.42 & 9.27 & 0.50 \\
\hline H. carteri & 0.42 & 0.16 & 0.59 & 0.93 & 0.11 & 0.81 & 0.23 & 0.20 & - & - & - & - & - & - & - & 0.51 & 1.32 & - & - & 0.76 & 0.32 & 0.48 & 0.40 & - & 1.25 & - \\
\hline arcia spp. & - & - & - & - & - & - & - & - & - & - & - & - & - & - & - & - & - & - & - & - & - & - & - & - & - & - \\
\hline S. apsteinii & 0.28 & - & - & 0.46 & - & - & - & - & - & - & - & - & - & - & - & - & 0.44 & - & - & - & - & 0.16 & - & 0.21 & 0.50 & - \\
\hline R. clavigera & 0.28 & - & 0.20 & - & 0.22 & 0.20 & - & - & - & - & - & - & 0.15 & - & 1.03 & - & 0.88 & - & 7.02 & - & 0.32 & 1.76 & - & 0.21 & 0.50 & - \\
\hline Syracosphaera spp. & 0.56 & 0.3 & 0.59 & 1.62 & 0.65 & 3.05 & 0.47 & 0.6 & - & - & 01 & 0.5 & - & - & 3.3 & 19.49 & - & 3.51 & 0.88 & 1.5 & 3.94 & 5.45 & 3.78 & 0.84 & 2.26 & - \\
\hline U. tenuis & - & - & - & - & - & 0.41 & - & 0.20 & - & - & 11.20 & 1.64 & - & 2.99 & 22.74 & 20.25 & 6.58 & - & 21.05 & 14.50 & 9.15 & 12.18 & 3.39 & 1.25 & - & 2.488 \\
\hline U. sibogc & 5.37 & $0.4 \varepsilon$ & 2.37 & 3.0 & $1.6^{3}$ & 3.87 & 1.7 & 2.58 & - & 2.6 & 5.24 & - & 1.6 & 1.20 & 5.94 & 1.52 & - & - & 1.75 & - & 0.63 & 3.04 & 3.19 & 1.25 & 3.26 & 0.498 \\
\hline Holococcolith spp. & - & - & - & - & - & - & - & 0.79 & - & - & - & - & - & - & 0.26 & - & - & 3.31 & 0.88 & - & - & - & - & - & - & - \\
\hline Undetermined spp. & - & - & - & - & - & - & - & - & - & - & - & - & - & - & - & - & - & - & - & - & 0.16 & - & 0.20 & - & - & - \\
\hline
\end{tabular}



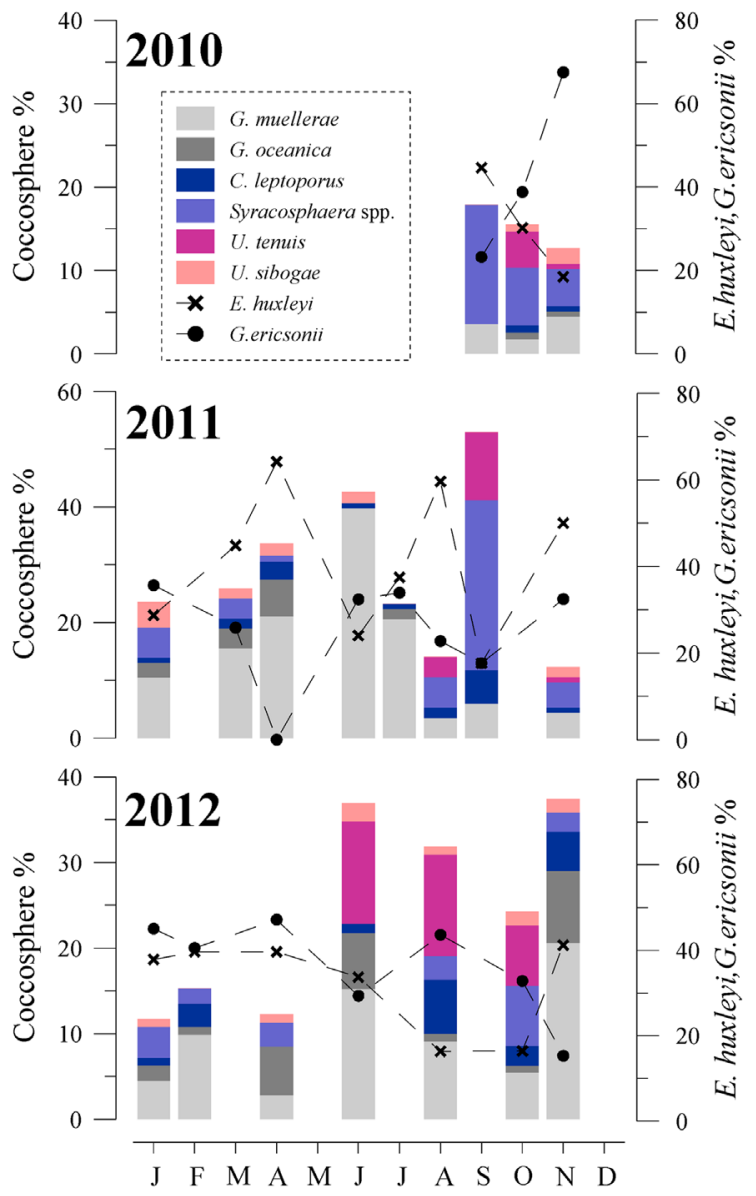
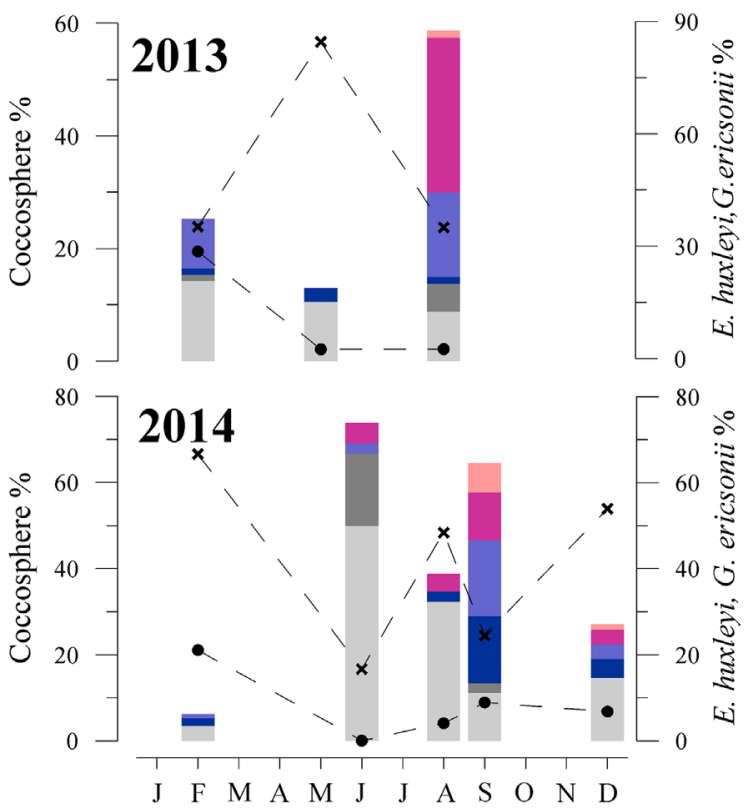

Fig. 5. Monthly relative abundances of the eight most significant coccolithophores within the living community, from September 2010 to December 2014.

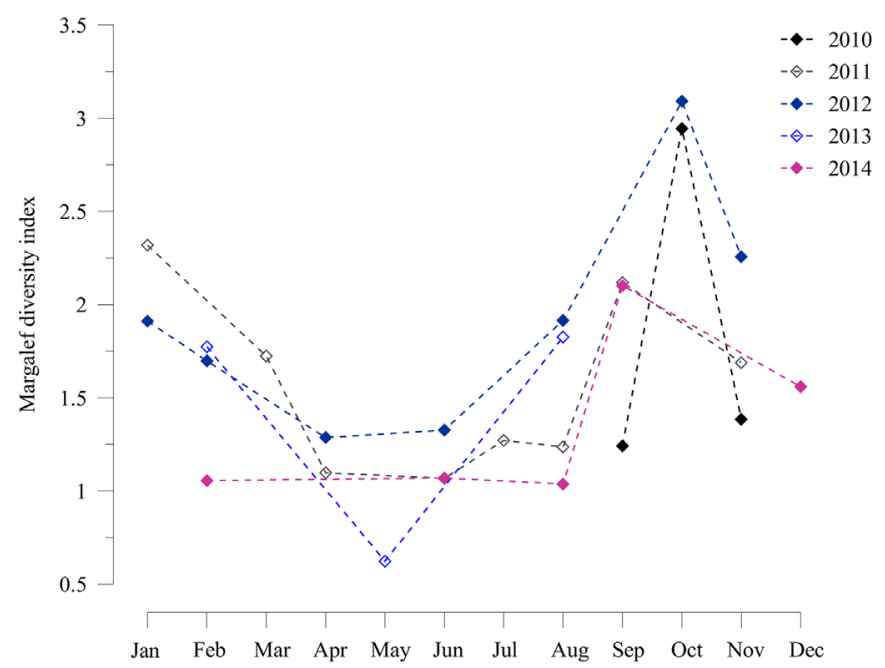

Fig. 6. Values of Margalef diversity index for each sample from September 2010 to December 2014

dwelling species (Guerreiro et al., 2013), capable of withstanding coastal turbulence and well-adapted to the nutrient-rich coastal environment (Silva et al., 2008). However, the dominance of this species in the coccolithophore flora during most of the year, through high and low productivity periods, show its cosmopolitan and opportunistic behavior (e.g. Winter et al., 1994; Baumann et al., 2000; Andruleit, 2007). G. ericsonii has been said to be similar to E. huxleyi in ecologic demands (Haidar and Thierstein, 2001), abundant at a wide range of ecologic conditions but preferring subsurface waters with enhanced nutrient concentrations (Baumann et al., 2008). The similarity between these two species and its positive correlation with the environmental variables nitrate and phosphate is well expressed in the CCA triplot (Fig. 7), corroborating their affinity to conditions with high nutrient content. Therefore, the spring months, especially from the end of March to May, should be characterized by relatively low SSTs $\left(15-17^{\circ} \mathrm{C}\right)$, mixing of the upper water column and higher nutrient conditions (maxima values: $3.76 \mu \mathrm{mol}^{-1}$ for nitrate and $0.43 \mu \mathrm{mol}^{-1}$ for phosphate). Table 6 summarizes the ecological preferences of the most significant taxa within the living community (coccospheres), which represent about 85\% of the assemblage. During April 2011, however, a significant decrease in nutrients concentration, followed the increase in E. huxleyi abundances may reflects the rapid growth and uptake capacity of this species within nutrient-rich and turbulent environments (e.g. Sprengel et al., 2002; Silva et al., 2008; Guerreiro et al., 2013). The simultaneous fall also observed in the G. ericsonii abundances may indicate that during the highest produc tivity period this species should not be as well adapted to compete with E. huxleyi. Studies from Guerreiro et al. (2013) refer E. huxleyi as the coccolithophore species that benefited the most from favorable nutrient conditions within the sunlit layer, which is in agreement with our findings. This same pattern, with very high relative abundances of $E$. huxleyi and near-zero abundances of G. ericsonii repeats itself in May 2013, although a moderate productivity during this month is observed. However, May 2013 is also the month that records the second largest concentration of total coccoliths (Fig. 4), indicating that the higher productivity interval, in which the exponential growth of the cells (coccospheres) may have occurred, took place previously.

The occurrence of E. huxleyi overcalcified morphotype during the colder months, particularly during April 2011 (see Table 2), is another important finding of this interval and corroborates the oceanographic 


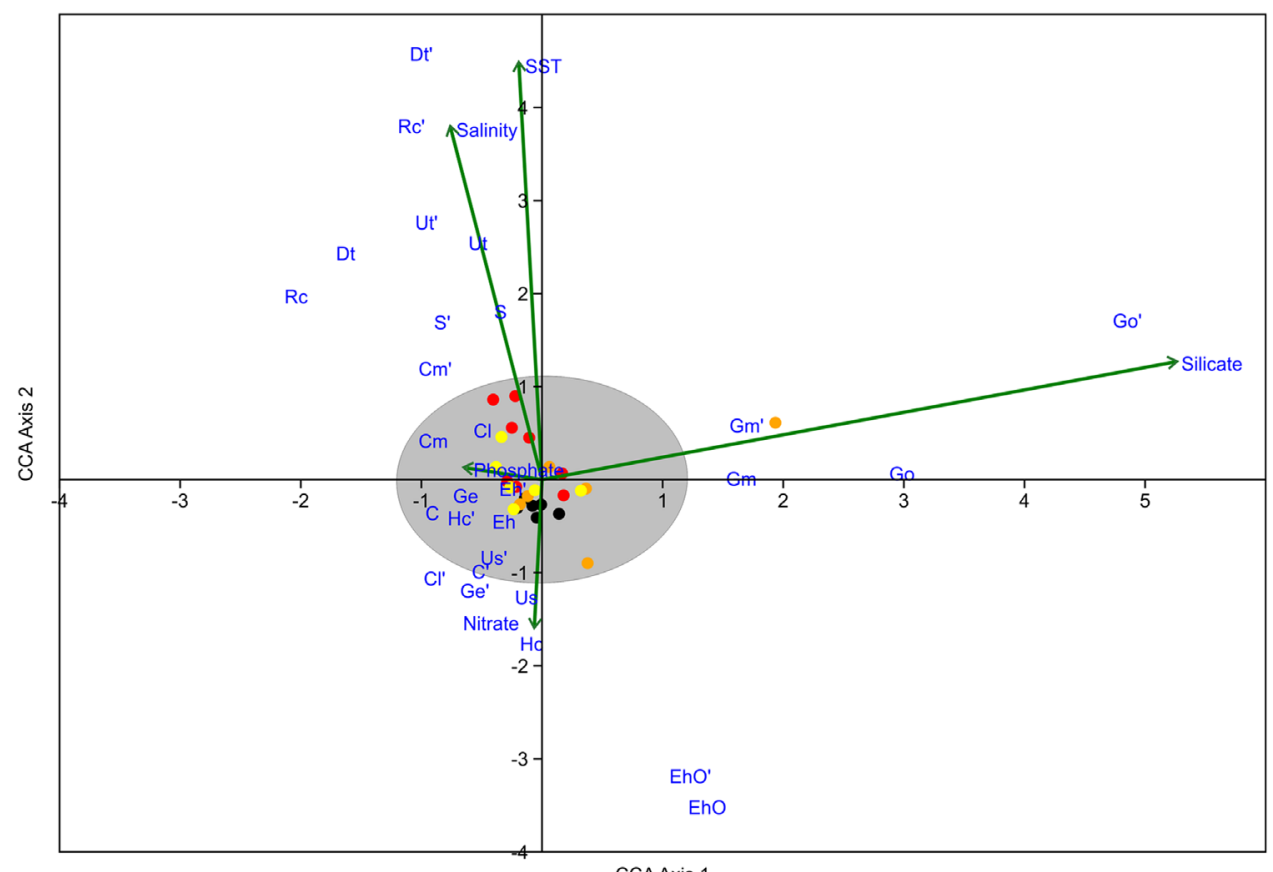

CCAAxis 1

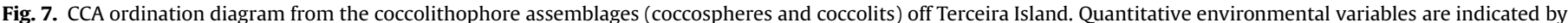

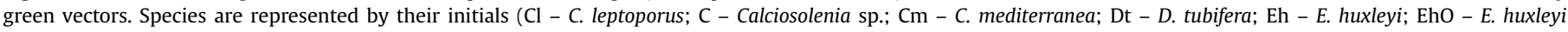

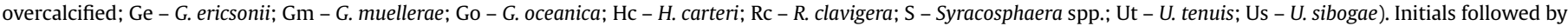

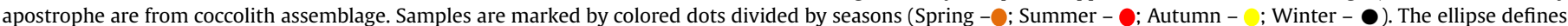
the region that contains $95 \%$ of all samples. (For interpretation of the references to color in this figure legend, the reader is referred to the web version of this article.)

Table 4

Eigenvalues and respective percentage variance in the CCA analysis performed in the coccolithophore assemblages off Terceira Island.

\begin{tabular}{llr}
\hline Axis & Eigenvalue & $\%$ \\
\hline 1 & 0.148 & 57.10 \\
2 & 0.851 & 32.86 \\
3 & 0.019 & 7.52 \\
\hline
\end{tabular}

conditions already inferred. Recent studies also discuss the occurrence of an overcalcified morphotype, for instance: in the eastern Mediterranean, during the most productive months (Dimiza et al.,2008); in the northernmost stations of a North Atlantic transect, associated with well mixed high-nutrient conditions (Schiebel et al., 2011); and in plankton assemblages influenced by upwelling (Henderiks et al., 2012). Likewise, older literature associates a "closed" morphotype of E. huxleyi to cold waters (e.g. McIntyre and Bé, 1967; Hagino, 1997). The April averaged SST map (Fig. 2c), shows an influence of subpolar waters in the sampling area during 2011. At the same time, a water column mixing and a subsequent enhanced nutrient concentration should have occurred, leading to the proliferation of this morphotype. Moreover, a patch of cold water can be observed along the south coast of Terceira, which may correspond to the signature of a localized upwelling event, supporting another oceanographic influence for the presence of this morphotype. The position of $E$. huxleyi "closed" morphotype in the CCA triplot (Fig. 7) corroborates its affinity for lower SST and less saline waters, as well as higher nitrate content. According to Fig. 2c, it seems there is also influence of subpolar waters during April 2013 and 2014, although in lesser degree. However, the lack of samples from these years does not allow us to make assumptions about the development of this overcalcified morphotype for those periods. In contrast, there is no record of this morphotype in our data for April 2012, which can be explained by the higher and unusual surface temperatures observed during this month.

At the end of spring, the maxima of G. muellerae observed in June
Table 5

Scores of the taxa, environmental variables and samples obtained in the CCA analysis performed in the coccolithophore assemblages off Terceira Island. Taxa abbreviations are the same as Fig. 7.

\begin{tabular}{|c|c|c|c|c|c|}
\hline & Axis 1 & Axis 2 & & Axis 1 & Axis 2 \\
\hline $\mathrm{Cl}$ & -0.619 & 0.549 & 3 & -0.044 & -0.408 \\
\hline $\mathrm{C}$ & -1.018 & -0.334 & 4 & -0.007 & -0.267 \\
\hline $\mathrm{Cm}$ & -1.077 & 0.438 & 5 & -0.205 & -0.304 \\
\hline Dt & -1.751 & 2.450 & 6 & 0.141 & -0.367 \\
\hline Eh & -0.234 & -0.355 & 7 & 0.378 & -0.897 \\
\hline EhO & 1.166 & -3.500 & 8 & -0.119 & -0.177 \\
\hline $\mathrm{Ge}$ & -0.450 & -0.202 & 9 & -0.183 & -0.265 \\
\hline $\mathrm{Gm}$ & 1.483 & 0.035 & 10 & 0.364 & -0.096 \\
\hline Go & 2.826 & 0.087 & 11 & 0.061 & 0.136 \\
\hline $\mathrm{Hc}$ & 0.006 & -1.653 & 12 & 1.935 & 0.612 \\
\hline Rc & -2.181 & 1.989 & 13 & 0.179 & -0.169 \\
\hline $\mathrm{S}$ & -0.443 & 1.833 & 14 & -0.214 & -0.076 \\
\hline Ut & -0.653 & 2.577 & 15 & -0.250 & 0.558 \\
\hline Us & -0.278 & -1.241 & 16 & -0.222 & 0.899 \\
\hline $\mathrm{Cl}^{\prime}$ & -0.721 & -1.086 & 17 & 0.167 & 0.067 \\
\hline $\mathrm{C}^{\prime}$ & -0.459 & -1.143 & 18 & -0.289 & -0.018 \\
\hline $\mathrm{Cm}^{\prime}$ & -1.069 & 1.226 & 19 & -0.405 & 0.860 \\
\hline $\mathrm{Dt}^{\prime}$ & -1.148 & 4.608 & 20 & -0.106 & 0.451 \\
\hline$E^{\prime}$ & -0.349 & -0.261 & 21 & -0.382 & 0.136 \\
\hline $\mathrm{EhO}^{\prime}$ & 1.008 & -3.165 & 22 & -0.337 & 0.459 \\
\hline $\mathrm{Ge}^{\prime}$ & -0.677 & -1.084 & 23 & -0.262 & -0.081 \\
\hline $\mathrm{Gm}^{\prime}$ & 1.499 & 0.608 & 24 & -0.235 & -0.318 \\
\hline $\mathrm{Go}^{\prime}$ & 4.682 & 1.745 & 25 & 0.323 & -0.118 \\
\hline $\mathrm{Hc}^{\prime}$ & -0.467 & -0.448 & 26 & -0.059 & -0.113 \\
\hline $\mathrm{Rc}^{\prime}$ & -0.902 & 3.770 & SST & -0.029 & 0.687 \\
\hline$S^{\prime}$ & -0.939 & 1.713 & Salinity & -0.117 & 0.582 \\
\hline $\mathrm{Ut}^{\prime}$ & -1.094 & 2.783 & Nitrate & -0.010 & -0.241 \\
\hline Us' & -0.563 & -0.819 & Phosphate & -0.095 & 0.019 \\
\hline 1 & -0.079 & -0.281 & Silicate & 0.809 & 0.195 \\
\hline 2 & -0.142 & -0.200 & & & \\
\hline
\end{tabular}

2011 and 2014 (Fig. 5; Tables 2 and 3) are remarkable. G. muellerae has been considered a temperate species (Cachão et al., 2000), as well as an indicator of cold water and/or waters of moderate to high productivity (e.g. Findlay and Flores, 2000; Colmenero-Hidalgo et al., 2004; 
Table 6

The main ecological preferences of the eight most significant coccolithophores within the living community, which represent about $85 \%$ of the assemblage.

\begin{tabular}{|c|c|c|c|c|c|}
\hline \multirow[t]{2}{*}{ Coccolithophores } & \multirow[t]{2}{*}{ Dominant season } & \multirow[t]{2}{*}{ SST $\left({ }^{\circ} \mathbf{C}\right)$} & \multicolumn{2}{|c|}{ Nutrients ( $\mu \mathrm{mol} \mathrm{l}^{-1}$ ) } & \multirow[t]{2}{*}{ Water column } \\
\hline & & & Nitrate & Phosphate & \\
\hline E. huxleyi & Spring & $15-17$ & High (3.76) & High (0.43) & Mixed \\
\hline G.ericsonii & Spring & $15-17$ & High (3.76) & High (0.43) & Mixed \\
\hline G. muellerae & End of spring & $18-21$ & Int. (1.02) & Int. (0.15) & Mixed \\
\hline G. oceanica & End of spring & $\sim 21$ & Int. (1.02) & Int. (0.15) & Mixed \\
\hline U. tenuis & Summer & $\sim 22$ & Low $(0.52)$ & Low $(0.1)$ & Stratified \\
\hline Syracosph. spp. & End of summer & $20-23.8$ & Low (0.13) & Low $(0.06)$ & Strat./mixed \\
\hline C. leptoporus & End of summer & $\sim 20$ & - & - & Strat./mixed \\
\hline U. sibogae & Late fall-winter & $14.5-20$ & Int. (1.62) & Int. (0.12) & Mixed \\
\hline
\end{tabular}

Bollmann, 1997; Schiebel et al., 2011). G. oceanica, which is often considered ecologically similar to G. muellerae, is also assumed as a maximum upwelling proxy (e.g. Sprengel et al., 2002; Andruleit et al., 2003; Guerreiro et al., 2013). In the present study G. oceanica has a behavior close to G. muellerae (Fig. 7), more evident during June 2014 and for the coccolith assemblage, in which the abundances reach $40 \%$ Table 3 ). According to our data June 2014 was the warmest one, with a registered temperature of $21^{\circ} \mathrm{C}$. It should be noted that this sampling was carried out already in the summer (see Table 1). Higher concentrations of nitrate and phosphate registered during the year of 2014 also reveal a productivity increase in surface layers (Fig. 3a and b). In this way, we may infer for this interval some mixture of the water column, possibly due to an occasional subpolar water mass influence or temporary mixing event, into a milder environmental context. According to Silva et al. (2008) G. oceanica is indicative of productive periods during summer, which supports our assumption.

In addition, our data shows that $G$. muellerae follows the two opportunistic or r-selected taxa E. huxleyi and G. ericsonii, developing after the period of maximum productivity known as the first stage of the phytoplankton succession described by Margalef. Its development occurs also before the dominance of the K-selected taxa, or equilibrium species, coincident with the later stage of the succession (Margalef, $1974 ;$ 1978). The preferential development of the genus Gephyrocapsa after E. huxleyi was also observed by Silva et al. (2008) on distinct oceanographic context. Still during June 2014, the higher proportion of G. oceanica coccoliths in relation to its coccospheres may indicate a decrease in the production of new cells, i.e., a decay of this species population (Cachão and Oliveira, 2000). The lack of an immediately previous sample, however, does not allow us to detect the time interval when the optimum development of G. oceanica occurred.

Extremely high silicate concentrations were measured in May and June 2014 (Fig. 3c). The sample of June is located outside the 95\% of the overall sample distribution in the CCA diagram ordination, reflecting its anomalous behavior. The sample of May was excluded from the CCA analysis due to the absence of coccolithophore data. During March the concentration was already higher than during the remaining measured months, indicating that the silicate increment during the year of 2014 should have started at that time. Since there is not a known direct relation between silicate and the coccolithophore development, we need a mechanism responsible for both increases to explain these records, which in turn it is not easy to identify. Therefore, only an additional study of all phytoplankton groups present in the water column at the sampling time could help to understand what may have happened.

During summer to early fall (July-October) a gradual decrease of the total coccolithophore abundance is observed. Fig. 6 shows the Margalef diversity index (Margalef, 1968) for each sampled month, which estimates the species richness. According to this figure, the diversity is higher during October $(2010,2012)$ and lower during the spring months, more precisely in May 2013, associated with higher biomass values. Still during summer to early fall, the K-selected subtropical coccolithophore assemblage, mainly composed by U. tenuis, Syracosphaera spp., D. tubifera, $R$. clavigera and $C$. mediterranea., indicates the presence of surface warmer and saltier waters, as well as oceanographic conditions of reduced mixing and low nutrients concentration (Figs. 5 and 7).

$U$. tenuis, which thrives during this interval (July-October) and is rare during the remaining part of the year, prefers tropical to subtropical waters (Okada and McIntyre, 1979), dwelling in oligotrophic, nutrientdepleted conditions (Kleijne et al., 1989; Kleijne, 1993; Baumann et al., 2008). Although more abundant in the middle photic zone (Cros, 2001; Haidar and Thierstein, 2001; Dimiza et al., 2004), this species is also present in the upper layers (Knappertsbusch, 1990; Andruleit et al., 2003; Malinverno et al., 2003). U. tenuis can reach higher values during summer (Malinverno et al., 2009) and even dominate the summer coccolithophore flora in the Mediterranean Sea (Knappertsbusch, 1990), as well as off Bermuda during summer and fall (Haidar and Thierstein, 2001), which is in agreement with our findings. Concerning the present physico-chemical data, the highest cell densities of $U$. tenuis are associated with SSTs of $22^{\circ} \mathrm{C}$, low nitrate (close to $0.5 \mu \mathrm{mol} \mathrm{l}^{-1}$ ) and phosphate (about $0.10 \mu \mathrm{mol}^{-1}$ ) concentrations. Similar values were also found by Haidar and Thierstein (2001).

Silva et al. (2013) refer D. tubifera, another umbelliform species with the same ecological requirements of $U$. tenuis (e.g. Ziveri et al., 2000, 2004; Oviedo et al., 2014), as the main representative of the summer coccolithophore flora at the north of Terceira Island (Azores), being absent during spring conditions. This same study did not mention $U$. tenuis at all, one of the most abundant species found in the present study during summer at the south of Terceira Island. Studies performed in the western North Atlantic at latitudes similar to those of our study refer Umbellosphaera spp. as the third most abundant taxa within the coccolithophore assemblage (Haidar and Thierstein, 2001). Schiebel et al. (2011) also refer the presence of $U$. tenuis in the southernmost station of a N-S transect in the North Atlantic, coincident with the Azores Front-Current System. This discrepancy between our results and those published by Silva et al. (2013) may be due to the adopted methodology, since using inverted microscope to count phytoplankton cells underestimate the coccolithophore counting, especially of the smaller and delicately structured species (Bollmann et al., 2002; O'Brien et al., 2013).

Syracosphaera spp., which mainly includes Syracosphaera pulchra, has the highest abundances during September, showing moderate occurrences in August and October. Beaufort and Heussner (2001) refer S. pulchra as an autumn species whereas for Silva et al. (2008, 2009) S. pulchra is one of the most abundant taxon during summerearly autumn, being associated with transition periods from upwelling to downwelling seasons. Besides, these same authors suggest that $S$. pulchra seems to tolerate cold waters under weak upwelling condition. In contrast, Hagino et al. (2000) relate this species with stable stratified waters. According to our results, the highest abundances of $S$. pulchra occur especially during the end of summer to early fall, in which the typical summer environmental conditions (stratified waters, high SST and low nutrient content) may give rise to some vertical mixing of the water column, slight SST reduction and nutrients concentration increase, revealing a transition in the environmental conditions. Although this interpretation, the highest cell densities of S. pulchra are 
associated with SSTs ranging from 20 to $23.8^{\circ} \mathrm{C}$ and low nutrients concentration $\left(0.13 \mu \mathrm{mol} \mathrm{l}^{-1}\right.$ for nitrate and $0.06 \mu \mathrm{mol} \mathrm{l}^{-1}$ for phosphate). However, the missing information from September 2010 and 2014 could raise these values. C. leptoporus does not belong to the group of the most important species identified in the current work, but is present all over the year off Terceira Island. The ubiquity is a characteristic of this species that, in one hand, is considered with oceanic affinity and an optimal growth within oligotrophic conditions (Giraudeau, 1992; Sprengel et al., 2002; Guerreiro et al., 2014) and, on the other hand, as a species with a tendency towards cooler waters and nutrient-rich environments, with a position close to G. ericsonii and G. muellerae (Boeckel et al., 2006). The variety of environments associated to $C$. leptoporus, which is believed to be due to the occurrence of this species as different morphotypes (Knappertsbusch et al., 1997; Baumann and Sprengel, 2000), is expressed in our data (Figs. 5 and 7). However, the highest abundances of this species are recorded in the end of summer (September 2014).

During late fall to winter (November-February), an overall coccolithophore abundance increase seems to occur, due to the proliferation of the eutrophic species E. huxleyi and G. ericsonii. A reduction in the species diversity also begins and continues onto spring. $U$. sibogae is another omnipresent species, although low significant in the current work, with some affinity for this interval. Its position in the CCA ordination diagram reveals a positive correlation with the nutrients, more significant with the nitrate. Thus, this interval is potentially related with low SST, moderate nutrients concentration and surface mixed layer deepening. It should be noticed that this was the hardest period for sampling the water column, either due to climate conditions or technical issues.

Our data shows also a considerable interannual variability. The year of 2011 includes the highest coccolithophore abundances (April), as well as the major frequency of maxima values in the monthly absolute abundances for both coccospheres and coccoliths (Fig. 4). This fact may indicate that 2011 was, in general, the most productive year for coccolithophore community. During 2012, characterized by milder environmental conditions, the total coccolithophore abundances decrease while the diversity of the community increase, as shown in Figs. 4 and 6. This difference between 2011 and 2012 is also well expressed in the species records. For instance, the favorable conditions for the development of $U$. tenuis, related with warmer and oligotrophic waters as already mentioned, begin earlier in 2012 (June) than in 2011 (August). This fact cannot be explained only by the SST registered in those months of June and August, but by a sequence of mechanisms that occurred previously. The year of 2014 seems to have characteristics similar to 2011, shown by the close patterns provided in the Margalef diversity index, although with milder temperature range.

This study revealed that the coccolithophore community noticeably responds to variations in main physical temperature and salinities properties of the water column, mainly due to seasonality, as well as on the chemical variations on main traditional nutrients (nitrates, phosphates) including silicates. This corroborates the importance of coccolithophores as proxies of marine environmental conditions in the past

\section{Conclusions}

The present coccolithophore survey aimed to describe the annual development of this phytoplankton group, from September 2010 to December 2014, in the vicinity of Terceira Island. The main conclusions of this study are:

1. There is a clear seasonal distribution of the living coccolithophore community, as well a considerable interannual variability;

2. The highest coccolithophore abundances are observed during the spring months, especially due to the smaller species $E$. huxleyi and $G$. ericsonii. This interval is potentially related with relatively low SSTs, mixing of the upper water column and higher nutrient conditions;
3. The highest biomass period is registered during April 2011 and is due to the contribution of E. huxleyi, which includes its overcalcified morphotype. The influence of a subpolar flux with subsequent water mixing and enhanced nutrient concentration may be the source of this morphotype;

4. The highest abundances of $G$. muellerae are recorded during June 2011 and 2014, indicating that this species develops after the period of maximum productivity, in which the r-selected taxa predominate, and before the dominance of the K-selected taxa, which coincide with the later stage of the phytoplankton succession described by Margalef;

5. G. oceanica has a behavior close to G. muellerae. The higher abundances observed in June 2014 reveal the preference of this species for mild upwelled waters;

6. During summer to early fall a gradual decrease of the overall coccolithophore abundance is observed, with the concomitant increase in biodiversity. The subtropical coccolithophore assemblage indicates the presence of surface warmer and saltier waters, as well as oceanographic conditions of reduced mixing and low nutrients concentration;

7. $U$. tenuis is the most abundant subtropical species that dwells in the upper photic zone off Terceira Island during the summer, being associated to high SSTs, stratified waters and low nitrate and phosphate concentrations;

8. The major abundances of S. pulchra are observed especially during the end of summer to early fall, in which a transition in the environmental conditions, with some vertical mixing of the water column, slight SST reduction and nutrients concentration increase may occur;

9. During late fall to winter there is a trend for an overall coccolithophore abundance increase, with a simultaneous reduction in species diversity. Thus, this interval is potentially related with low SSTs, moderate nutrients concentration and surface mixed layer deepening;

10. The interannual variability is marked by colder and productive waters during 2011, with the consequent increase in the total coccolithophore abundances, as well as by milder conditions during 2012, responsible for the community diversity increase;

11. Similarities between 2011 and 2014 are visible, although with stronger temperature range during the former.

\section{Acknowledgments}

This research was supported by the Azores Regional Science Fund (M3.1.7/F/028/2011 and M3.1.7/F/003/2010) and is part of the Project ROPICO-2 "Responses of phytoplankton communities from the Subtropical North Atlantic Gyre to increasing $\mathrm{CO}_{2}$ concentrations and consequent carbonate chemistry changes in the ocean, Azores"; (PTDC/ AAC-CLI/112735/2009). Filters were mounted and analyzed in NanoLab, Instituto Dom Luiz, Lisbon University (IDL). SEM observations were made at the Institut de Ciències del Mar (ICM-CSIC, Barcelona, Spain). A special thanks to José-Manuel Fortuño for all help with the SEM analysis. The authors are deeply grateful to the boat crew and collaborators, responsible for the water monthly sampling. Constructive criticism and helpful suggestions from the anonymous reviewer are gratefully acknowledged by the authors. The authors are also greatly thankful to Vasco Valadares (GeoSurveys) for all help with the location figure.

\section{Appendix A. Calcareous nannofossil taxonomic list}

Algirosphaera robusta (Lohmann, 1902) Norris (1984)

Alisphaera gaudii Kleijne et al. (2001)

Braarudosphaera bigelowii (Gran and Braarud, 1935) Deflandre (1947) 
Calcidiscus leptoporus (Murray and Blackman, 1898) Loeblich and Tappan (1978)

Calciosolenia sp. Gran (1912)

Calciosolenia brasiliensis (Lohmann, 1902) Young et al. (2003)

Canistrolithus sp. Jordan and Chamberlain, 1993

Coccolithus pelagicus braarudii (Gaarder, 1962a) Geisen et al., 2002

Coronosphaera mediterranea (Lohmann 1902) Gaarder, in Gaarder and Heimdal (1977) (72)

Discosphaera tubifera (Murray and Blackman, 1898) Ostenfeld (1900)

Emiliania huxleyi (Lohmann, 1902) Hay and Mohler, in Hay et al. (1967)

Florisphaera profunda var. profunda Okada and Honjo (1973)

Florisphaera profunda var. elongata Okada and MacInyre (1980)

Gephyrocapsa ericsonii McIntyre and Bé, 1967

Gephyrocapsa muellerae Bréhéret (1978)

Gephyrocapsa oceanica Kamptner (1943)

Gephyrocapsa ornata Heimdal (1973)

Helicosphaera carteri var. carteri (Wallich, 1877) Kamptner (1954)

Helicosphaera carteri var. hyalina (Gaarder, 1970) Jordan and Young (1990)
Helicosphaera carteri var. wallichii (Lohmann) Theodoridis (1984)

Michaelsarcia adriaticus (Schiller, 1930) Manton et al. (1984)

Michaelsarsia elegans Gran (1912); emend. Manton et al. (1984)

Rhabdosphaera sp. Haeckel, 1894

Rhabdosphaera clavigera Murray and Blackman (1898)

Scyphosphaera apsteinii Lohmann (1902)

Syracosphaera sp. Lohmann (1902)

Syracosphaera anthos (Lohmann, 1912) Janin (1987)

Syracosphaera anthos HOL (Lohmann, 1912) Janin (1987), formerly Periphyllophora mirabilis (Schiller) Kamptner, Halldal and Markali (1955)Syracosphaera bannockii (Borsetti and Cati, 1976) Cros et al. (2000b)

Syracosphaera halldalii Gaarder ex Jordan and Green (1994)

Syracosphaera histrica Kamptner, 1941

Syracosphaera molischii Schiller (1925)

Syracosphaera pulchra Lohmann (1902)

Syracosphaera tumularis Sánchez-Suárez (1990)

Umbellosphaera tenuis (Kamptner, 1937) Paasche, in Markali and Paasche (1955)

Umbilicosphaera sibogae (Weber-van Bosse, 1901), Gaarder (1970)

Umbilicosphaera hulburtiana Gaarder (1970)

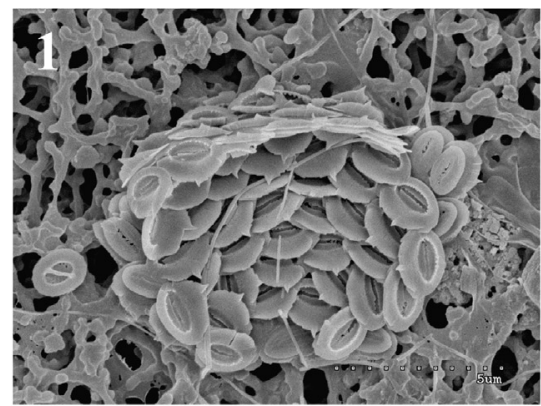

Alisphaera gaudii

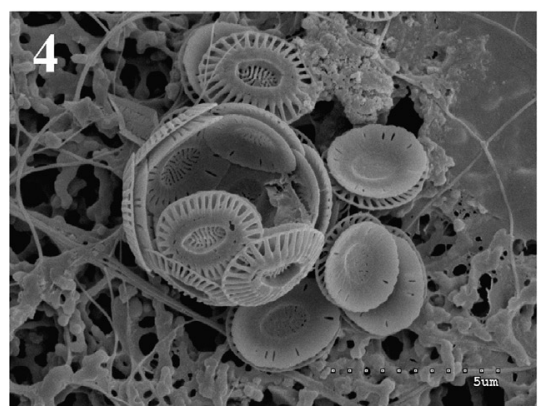

Emiliania huxleyi type A

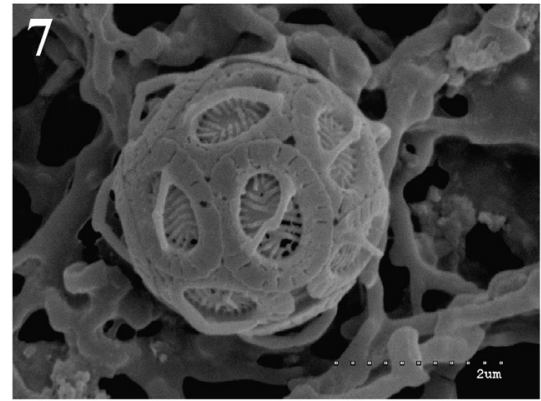

Gephyrocapsa ericsonii

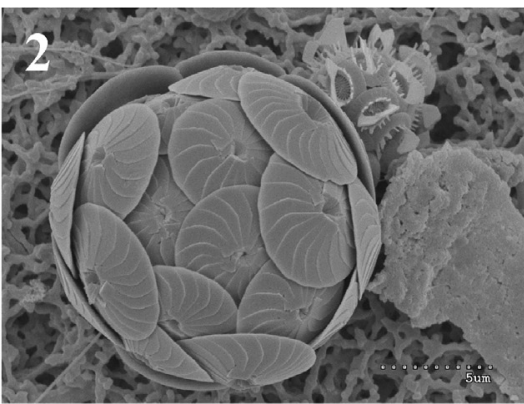

Calcidiscus leptoporus and Gephyrocapsa ornata

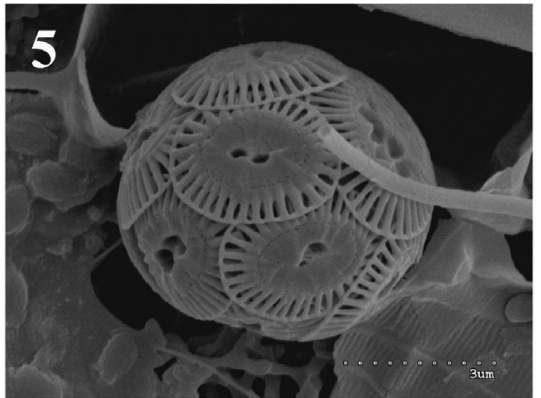

E. huxleyi type A overcalcified

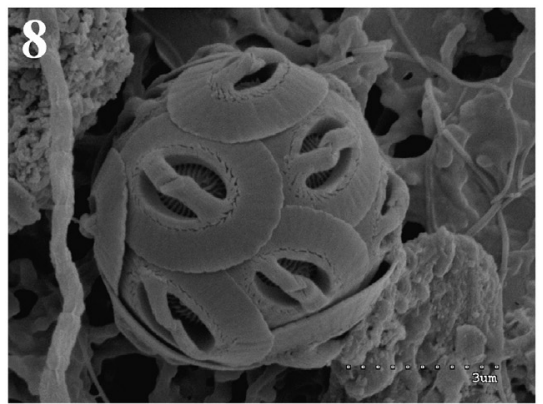

Gephyrocapsa muellerae

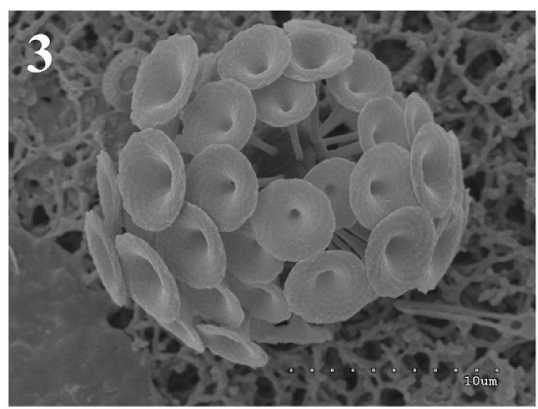

Discosphaera tubifera

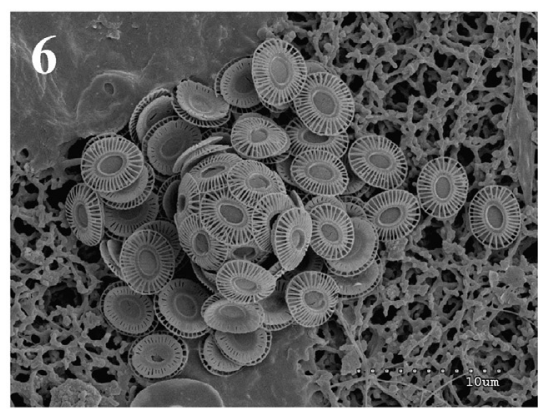

E. huxleyi type C

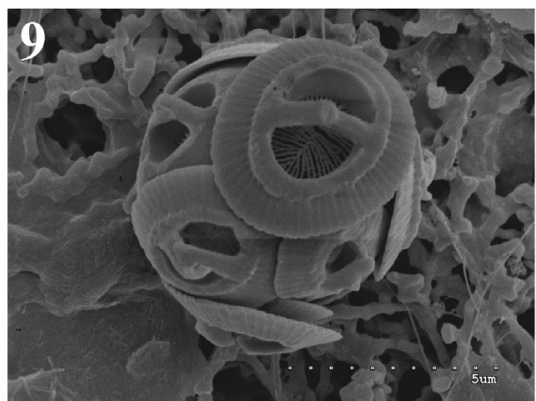

Gephyrocapsa oceanica

Plate 1. Scanning electron micrographs I. 


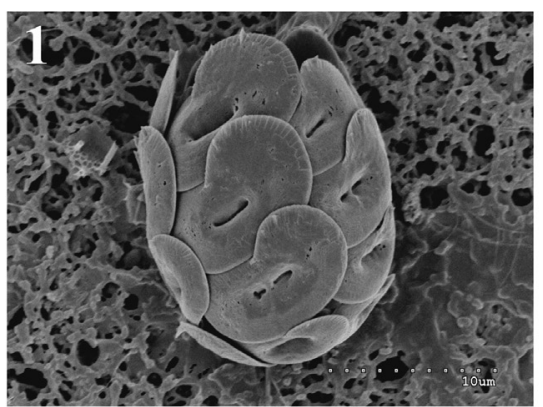

Helicosphaera carteri

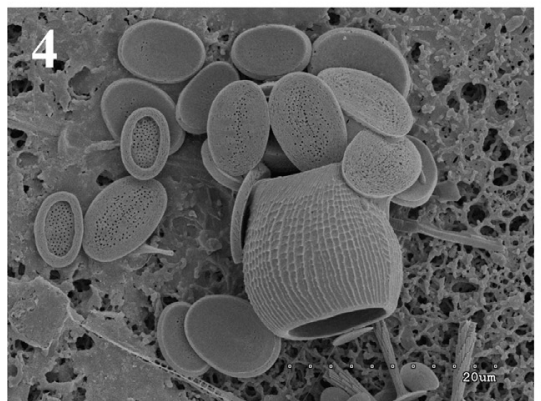

Scyphosphaera apsteinii

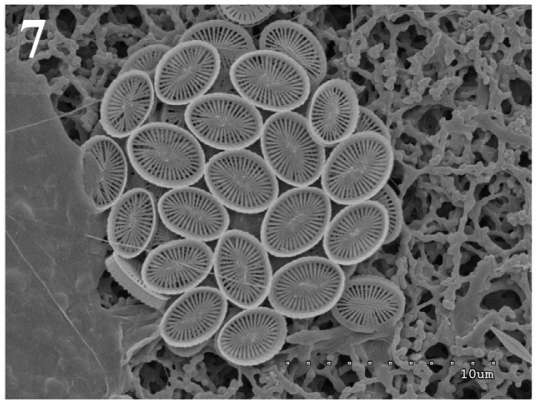

Syracosphaera tumularis

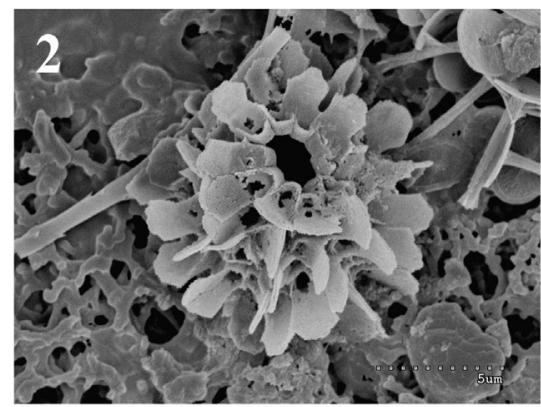

Syracosphaera anthos HOL

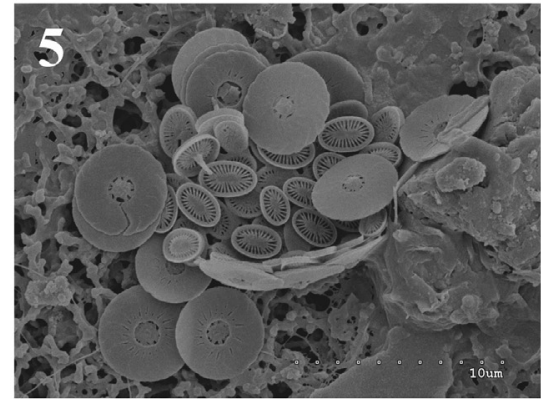

Syracosphaera anthos

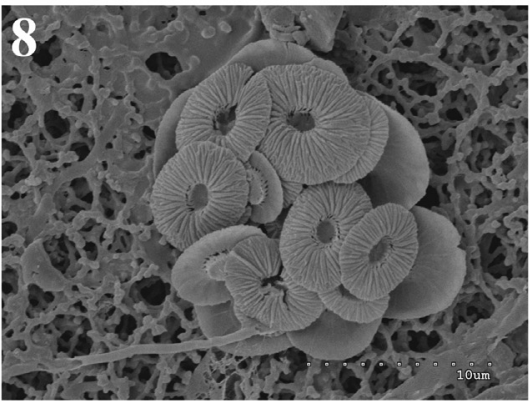

Umbellosphaera tenuis

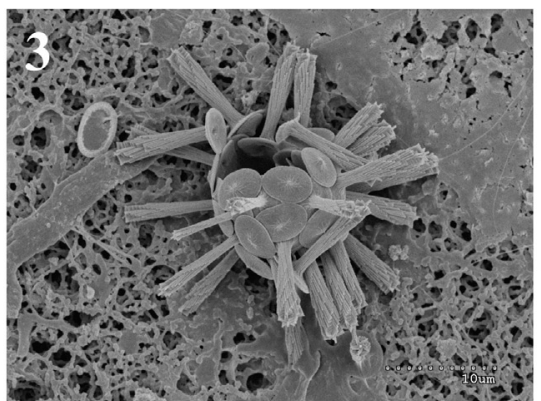

Rhabdosphaera clavigera

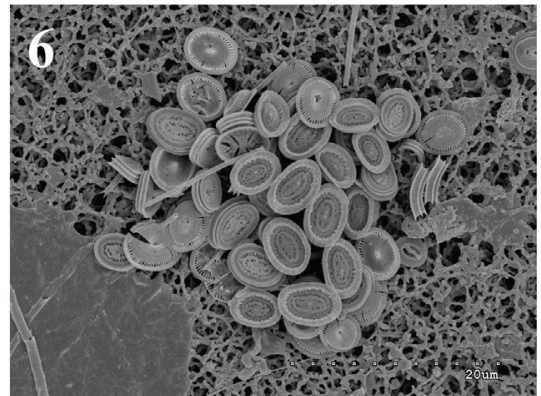

Syracosphaera pulchra

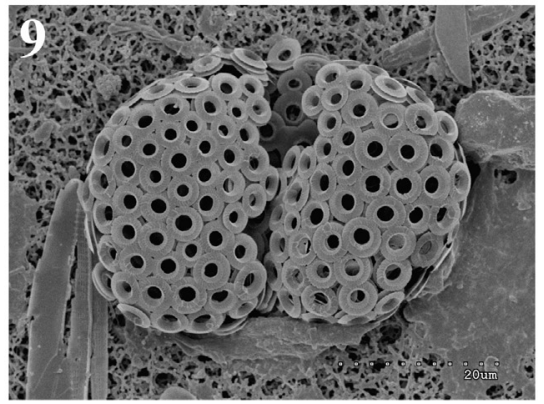

Umbilicosphaera sibogae

Plate 2. Scanning electron micrographs II.

\section{Appendix B:}

Plate 1 and Plate 2.

\section{References}

Andruleit, H., 1997. Coccolithophore fluxes in the Norwegian-Greenland Sea: Seasonality and assemblage alterations. Mar. Micropaleontol. 31, 45-64. http://dx doi.org/10.1016/S0377-8398(96)00055-2.

Andruleit, H., 2007. Status of the Java upwelling area (Indian Ocean) during the oligotrophic northern hemisphere winter monsoon season as revealed by coccolithophores. Mar. Micropaleontol. 64, 36-51. http://dx.doi.org/10.1016/j. marmicro.2007.02.001.

Andruleit, H., Stäger, S., Rogalla, U., Čepek, P., 2003. Living coccolithophores in the northern Arabian Sea: ecological tolerances and environmental control. Mar. Micropaleontol. 49, 157-181. http://dx.doi.org/10.1016/S0377-8398(03) 00049-5.

Baumann, K., Sprengel, C., 2000. Morphological variations of selected coccolith species in a sediment trap north of the Canary Islands. J. Nannoplankt. Res. 22, 185-193.

Baumann, K., Boeckel, B., Čepek, M., 2008. Spatial distribution of living coccolithophores along an east- west transect in the subtropical South Atlantic. J. Nannoplankt. Res. 30, 9-21.

Baumann, K.-H., Andruleit, H., Samtleben, C., 2000. Coccolithophores in the Nordic Seas: comparison of living communities with surface sediment assemblages. Deep Sea Res. Part II Top. Stud. Oceanogr. 47, 1743-1772. http://dx.doi.org/ 10.1016/S0967-0645(00)00005-9.

Beaufort, L., Heussner, S., 2001. Seasonal dynamics of calcareous nannoplankton on a West European continental margin: the Bay of Biscay. Mar. Micropaleontol. 43, 27-55. http://dx.doi.org/10.1016/S0377-8398(01)00020-2.

Berger, W.H., Smetacek, V.S., Wefer, G., 1989. Ocean productivity and paleoproductivity- An overview. In: Berger, W.H., Smetacek, V.S., Wefer, G. (Eds.), Productivity of the Ocean: Present and Past. John Wiley, Hoboken, N. J., pp. 1-34.

Boeckel, B., Baumann, K.-H., Henrich, R., Kinkel, H., 2006. Coccolith distribution patterns in South Atlantic and Southern Ocean surface sediments in relation to environmental gradients. Deep Sea Res. Part I Oceanogr. Res. Pap. 53, 1073-1099. http://dx.doi.org/10.1016/j.dsr.2005.11.006.

Bollmann, J., 1997. Morphology and biogeography of Gephyrocapsa coccoliths in Holocene sediments. Mar. Micropaleontol. 29, 319-350.

Bollmann, J., Cortés, M., Haidar, A.T., Brabec, B., Close, A., Hofmann, R., Palma, S., Tupas, L., Thierstein, H.R., 2002. Techniques for quantitative analyses of calcareous marine phytoplankton. Mar. Micropaleontol. 44, 163-185.

Bower, A.S., von Appen, W.-J., 2008. Interannual variability in the pathways of the North Atlantic current over the Mid-Atlantic ridge and the impact of topography. J. Phys. Oceanogr. 38, 104-120. http://dx.doi.org/10.1175 2007JPO3686.1.

Cachão, M., Oliveira, A., 2000. (Cocco)liths versus (cocco)spheres: approaching the ecological performance of coccolithophores. J. Nannoplankt. Res. 22, 29-34.

Cachão, M., Oliveira, A., Vitorino, J., 2000. Subtropical winter guests, offshore Portugal. J. Nannoplankt. Res. 22, 19-26.

Chen, Y.L., Chen, H.-Y., Chung, C.-W., 2007. Seasonal variability of coccolithophore abundance and assemblage in the northern South China Sea. Deep Sea Res. Il 54, 1617-1633. http://dx.doi.org/10.1016/j.dsr2.2007.05.005.

Colmenero-Hidalgo, E., Flores, J.-A., Sierro, F.J., Bárcena, M.Á., Löwemark, L. Schönfeld, J., Grimalt, J.O., 2004. Ocean surface water response to short-term climate changes revealed by coccolithophores from the Gulf of Cadiz (NE Atlantic) and Alboran Sea (W Mediterranean). Palaeogeogr. Palaeoclimatol. Palaeoecol. 205, 317-336. http://dx.doi.org/10.1016/j.palaeo.2003.12.014.

Cros, L., 2001. Planktonic coccolithophores of the NW Mediterranean (Ph.D. thesis), Universitat de Barcelona, 181pp.

Cros, L., Fortuño, J.-M., 2002. Atlas of Northwestern Mediterranean coccolithophores. Scientia Marina 66 (1), 1-186.

Dimiza, M.D., Triantaphyllou, M.V., Dermitzakis, M.D., 2004. Vertical distribution and ecology of living coccolithophores in the marine ecosystems of Andros 
Island (Middle Aegean Sea) during late summer 2001*. Hell. J. Geosci 43, 7-20. Dimiza, M.D., Triantaphyllou, M.V., Dermitzakis, M.D., 2008. Seasonality and ecology of living coccolithophores in Eastern Mediterranean coastal environments (Andros Island, Middle Aegean Sea). Micropaleontology 54, 159-175.

Findlay, C.S., Flores, J.A., 2000. Subtropical front fluctuations south of Australia (45 Н 09 HS, 146 Н 17 HE) for the last 130 ka years based on calcareous nannoplankton. Mar. Micropaleontol. 40, 403-416.

Frada, M., Young, J., Cachão, M., Lino, S., 2010. A guide to extant coccolithophores (Calcihaptophycidae, Haptophyta) using light microscopy. J. Nannoplankt. Res. 31, 58-112.

Giraudeau, J., 1992. Distribution of Recent nannofossils beneath the Benguela system: Southwest African continental margin. Mar. Geol. 108, 219-237. http://dx. doi.org/10.1016/0025-3227(92)90174-G.

Giraudeau, J., Bailey, W., 1995. Spatial dynamics of coccolithophore communities during an upwelling event in the Southern Benguela system. Cont. Shelf Res. 15, 1825-1852.

Giraudeau, J., Monteiro, P.M.S., Nikodemus, K., 1993. Distribution and malformation of living coccolithophores in the northern Benguela upwelling system off Namibia. Mar. Micropaleontol. 22, 93-110. http://dx.doi.org/10.1016/0377-8398 (93)90005-I.

Gould, W., 1985. Physical oceanography of the Azores front. Prog. Oceanogr. 14, 167-190. http://dx.doi.org/10.1016/0079-6611(85)90010-2.

Guerreiro, C., Oliveira, A., de Stigter, H., Cachão, M., Sá, C., Borges, C., Cros, L., Santos, A., Fortuño, J.-M., Rodrigues, A., 2013. Late winter coccolithophore bloom off central Portugal in response to river discharge and upwelling. Cont. Shelf Res. 59, 65-83. http://dx.doi.org/10.1016/j.csr.2013.04.016.

Guerreiro, C., Sá, C., de Stigter, H., Oliveira, A., Cachão, M., Cros, L., Borges, C. Quaresma, L., Santos, A.I., Fortuño, J.-M., Rodrigues, A., 2014. Influence of the Nazaré Canyon, central Portuguese margin, on late winter coccolithophore assemblages. Deep Sea Res. Part II Top. Stud. Oceanogr. 104, 335-358. http://dx. doi.org/10.1016/j.dsr2.2013.09.011.

Hagino, K., Okada, H., Matsuoka, H., 2000. Spatial dynamics of coccolithophore assemblages in the Equatorial Western-Central Pacific Ocean. Mar. Micropaleontol. 39, 53-72. http://dx.doi.org/10.1016/S0377-8398(00)00014-1.

Hagino, K., 1997. Distribution of living coccolithophores in the western Pacific ocean off the coast of Northeast Japan. Fossils 63, 1-19.

Hagino, K., Okada, H., Matsuoka, H., 2005. Coccolithophore assemblages and morphotypes of Emiliania huxleyi in the boundary zone between the cold Oyashio and warm Kuroshio currents off the coast of Japan. Mar. Micropaleontol. 55, 19-47. http://dx.doi.org/10.1016/j.marmicro.2005.02.002.

Haidar, A.T., Thierstein, H.R., 2001. Coccolithophore dynamics off Bermuda (N. Atlantic). Deep Sea Res. Part II Top. Stud. Oceanogr. 48, 1925-1956. http://dx doi.org/10.1016/S0967-0645(00)00169-7.

Hansen, H.P., Koroleff, F., 1999. Determination of nutrients. In: Grasshoff, K., Kremling, K., Ehrhardt, M. (Eds.), Methods of Seawater Analysis, Third Edition, Wiley-VCH Verlag GmbH, Weinheim, Germany, http://dx.doi.org/10.1002/ 9783527613984.ch10.

Honjo, S., 1996. Fluxes of particles to the interior of the open oceans. In: Ittekkot, V., et al. (Eds.), Particle Flux in the Ocean, Scope 57. Wiley \& Sons, Chichester pp. 91-154.

Hay, W.W., 2004. Carbonate fluxes and calcareous nannoplankton. In: Thierstein, H., Young, J. (Eds.), Coccolithophores: From Molecular Process to Global Impact, 2004. Springer Verlag, pp. 509-528.

Henderiks, J., Winter, A., Elbrächter, M., Feistel, R., der Plas, A., Nausch, G., Barlow, R., 2012. Environmental controls on Emiliania huxleyi morphotypes in the Benguela coastal upwelling system (SE Atlantic). Mar. Ecol. Prog. Ser. 448, 51-66. http://dx.doi.org/10.3354/meps09535.

IOC, IHO and BODC, 2003. Centenary Edition of the GEBCO Digital Atlas; from $\langle$ www.bodc.ac.uk $\rangle$.

Jordan, R., Cros, L., Young, J., 2004. A revised classification scheme for living haptophytes. Micropaleontology 50 (1), 55-79.

Klein, B., Siedler, G., 1989. On the origin of the Azores Current. J. Geophys. Res. 94, 6159-6168.

Kleijne, A., 1993. Morphology, Taxonomy and Distribution of Extant Coccolithophorids (Calcareous Nannoplankton) (Ph.D. thesis). Vrije Universiteit, Amsterdam.

Kleijne, A., Kroon, D., Zevenboom, W., 1989. Phytoplankton and foraminiferal frequencies in northern Indian Ocean and Red Sea surface waters. Neth. J. Sea Res. 24, 531-539.

Knappertsbusch, M., 1990. Geographic distribution of modern coccolithophorids in the Mediterranean Sea and morphological evolution of Calcidiscus leptoporus, Dissertation. Zürich, ETH, p. 141.

Knappertsbusch, M., Cortes, M.Y., Thierstein, H.R., 1997. Morphologic variability of the coccolithophorid Calcidiscus leptoporus in the plankton, surface sediments and from the Early Pleistocene. Mar. Micropaleontol. 30, 293-317. http://dx.doi. org/10.1016/S0377-8398(96)00053-9.

Longhurst, A., Sathyendranath, S., Platt, T., Caverhill, C., 1995. An estimate of global primary production in the ocean from satellite radiometer data. J. Plankton Res. 17, 1245-1271. http://dx.doi.org/10.1093/plankt/17.6.1245.

Malinverno, E., Ziveri, P., Corselli, C., 2003. Coccolithophorid distribution in the Ionian Sea and its relationship to eastern Mediterranean circulation during late fall to early winter 1997. J. Geophys. Res. 108, 8115. http://dx.doi.org/10.1029/ 2002JC001346.

Malinverno, E., Triantaphyllou, M.V., Stavrakakis, S., Ziveri, P., Lykousis, V., 2009. Seasonal and spatial variability of coccolithophore export production at the South-Western margin of Crete (Eastern Mediterranean). Mar. Micropaleontol.
71, 131-147. http://dx.doi.org/10.1016/j.marmicro.2009.02.002.

Margalef, R., 1968. Perspectives in ecological theory. University of Chicago Press, p. 111.

Margalef, R., 1974. Ecología. Omega, Barcelona, p. 951.

Margalef, R., 1978. Life-forms of phytoplankton as survival alternatives in an unstable environment. Oceanol. Acta 1, 493-509.

McIntyre, A., Bé, A.W.H., 1967. Modern coccolithophoridae of the atlantic ocean-I. Placoliths and cyrtoliths. Deep Sea Res. Oceanogr. Abstr. 14, 561-597. http://dx doi.org/10.1016/0011-7471(67)90065-4.

Mergulhao, L.P., Guptha, M.V.S., Unger, D., Murty, V.S.N., 2013. Seasonality and variability of coccolithophore fluxes in response to diverse oceanographic regimes in the Bay of Bengal: Sediment trap results. Palaeogeogr. Palaeoclimatol. Palaeoecol. 371, 119-135. http://dx.doi.org/10.1016/j.palaeo.2012.12.024.

Moita, M.T., Silva, a, Palma, S., Vilarinho, M.G., 2010. The coccolithophore summerautumn assemblage in the upwelling waters of Portugal: Patterns of mesoscale distribution (1985-2005). Estuar. Coast. Shelf Sci. 87, 411-419. http://dx.doi. org/10.1016/j.ecss.2010.01.025.

O’Brien, C.J., Peloquin, J. a, Vogt, M., Heinle, M., Gruber, N., Ajani, P., Andruleit, H., Arístegui, J., Beaufort, L., Estrada, M., Karentz, D., Kopczyńska, E., Lee, R., Poulton, a J., Pritchard, T., Widdicombe, C., 2013. Global marine plankton functional type biomass distributions: coccolithophores. Earth Syst. Sci. Data 5, 259-276. http://dx.doi.org/10.5194/essd-5-259-2013.

Okada, H., McIntyre, A., 1979. Seasonal distribution of modern coccolithophores in the western North Atlantic Ocean. Marine Biol. 54, 319-328.

Oviedo, A.M., Ziveri, P., Álvarez, M., Tanhua, T., 2014. Is coccolithophore distribution in the Mediterranean Sea related to seawater carbonate chemistry? Ocean Sci. Discuss. 11, 613-653. http://dx.doi.org/10.5194/osd-11-613-2014.

Reverdin, G., Niiler, P., Valdimarsson, H., 2003. North Atlantic Ocean surface currents. J. Geophys. Res., 108. http://dx.doi.org/10.1029/2001JC001020.

Rost, B., Riebesell, U., 2004. Coccolithophores and the biological pump: responses to environmental changes. In: Thierstein, Hans R., Young, Jeremy R. (Eds.), Coc colithophores: From Molecular Processes to Global Impact. Springer, Berlin, pp. 99-125.

Santos, R., Hawkins, S., Monteiro, L., Alves, M., Isidro, E., 1995. Case Studies and Reviews: Marine research, resources and conservation in the Azores. Aquat. Conserv. Mar. Freshw. Ecosyst. 5, 311-354.

Schiebel, R., Brupbacher, U., Schmidtko, S., Nausch, G., Waniek, J.J., Thierstein, H.-R., 2011. Spring coccolithophore production and dispersion in the temperate eastern North Atlantic Ocean. J. Geophys. Res. 116, C08030. http://dx.doi.org/ 10.1029/2010JC006841.

Silva, A., Palma, S., Moita, M.T., 2008. Coccolithophores in the upwelling waters of Portugal: Four years of weekly distribution in Lisbon bay. Cont. Shelf Res. 28, 2601-2613. http://dx.doi.org/10.1016/j.csr.2008.07.009.

Silva, A., Palma, S., Oliveira, P.B., Moita, M.T., 2009. Composition and interannual variability of phytoplankton in a coastal upwelling region (Lisbon Bay, Portugal). J. Sea Res. 62, 238-249. http://dx.doi.org/10.1016/j.seares.2009.05.001.

Silva, A., Brotas, V., Valente, A., Sá, C., Diniz, T., Patarra, R.F., Álvaro, N.V., Neto, A.I., 2013. Coccolithophore species as indicators of surface oceanographic conditions in the vicinity of Azores islands. Estuar. Coast. Shelf Sci. 118, 50-59. http: //dx.doi.org/10.1016/j.ecss.2012.12.010.

Sprengel, C., Baumann, K.-H., Henderiks, J., Henrich, R., Neuer, S., 2002. Modern coccolithophore and carbonate sedimentation along a productivity gradient in the Canary Islands region: seasonal export production and surface accumulation rates. Deep Sea Res. Part II Top. Stud. Oceanogr. 49, 3577-3598. http://dx doi.org/10.1016/S0967-0645(02)00099-1.

Storz, D., Schulz, H., Waniek, J.J., Schulz-Bull, D.E., Kučera, M., 2009. Seasonal and interannual variability of the planktic foraminiferal flux in the vicinity of the Azores Current. Deep Sea Res. Part I Oceanogr. Res. Pap. 56, 107-124. http://dx. doi.org/10.1016/j.dsr.2008.08.009.

Sun, J., Gu, X.Y., Feng, Y.Y., Jin, S.F., Jiang, W.S., Jin, H.Y., Chen, J.F., 2014. Summer and winter living coccolithophores in the Yellow Sea and the East China Sea. Biogeosciences 11, 779-806. http://dx.doi.org/10.5194/bg-11-779-2014.

Waniek, J.J., Schulz-Bull, D.E., Blanz, T., Prien, R.D., Oschlies, A., Müller, T.J., 2005. Interannual variability of deep water particle flux in relation to production and lateral sources in the northeast Atlantic. Deep Sea Res. Part I Oceanogr. Res. Pap 52, 33-50. http://dx.doi.org/10.1016/j.dsr.2004.08.008.

Westbroek, P., Brown, C.W., Bleijswijk, J., van, Brownlee, C., Brummer, G.J., Conte, M., Egge, J., Fernández, E., Jordan, R., Knappertsbusch, M., Stefels, J., Veldhuis, M., van der Wal, P., Young, J., 1993. A model system approach to biological climate forcing. The example of Emiliania huxleyi. Glob. Planet. Change 8, 27-46. http: //dx.doi.org/10.1016/0921-8181(93)90061-R.

Winter, A., Jordan, R., Roth, P., 1994. Biogeography of living coccolithophores in ocean waters. In: Winter, A., Siesser, W. (Eds.), Coccolithophores. Cambridge University Press, Cambridge, pp. 161-177.

Young, J., Geisen, M., Cros, L., Kleijne, A., Sprengel, C., Probert, I., Ostergaard, J., 2003. A guide to extant coccolithophore taxonomy. J. Nannoplankt. Res. Spec (Issue 1-121).

Ziveri, P., Rutten, a, de Lange, G., Thomson, J., Corselli, C., 2000. Present-day coccolith fluxes recorded in central eastern Mediterranean sediment traps and surface sediments. Palaeogeogr. Palaeoclimatol. Palaeoecol. 158, 175-195. http: //dx.doi.org/10.1016/S0031-0182(00)00049-3.

Ziveri, P., Baumann, K.H., Böckel, B., Bollmann, J., Young, J.R., 2004. Biogeography of selected Holocene coccoliths in the Atlantic Ocean. In: Thierstein, H., Young, J. (Eds.), Coccolithophores: From Molecular Process to Global Impact, pp. 403-428. 